Document downloaded from:

http://hdl.handle.net/10251/83243

This paper must be cited as:

Vila Pastor, C.; Siller, H.; Rodríguez, C.; Bruscas Bellido, G.; Serrano, J. (2012). Economical and technological study of surface grinding versus face milling in hardened AISI D3 steel machining operations. International Journal of Production Economics. 138(2):273-283. doi:10.1016/j.ijpe.2012.03.028.

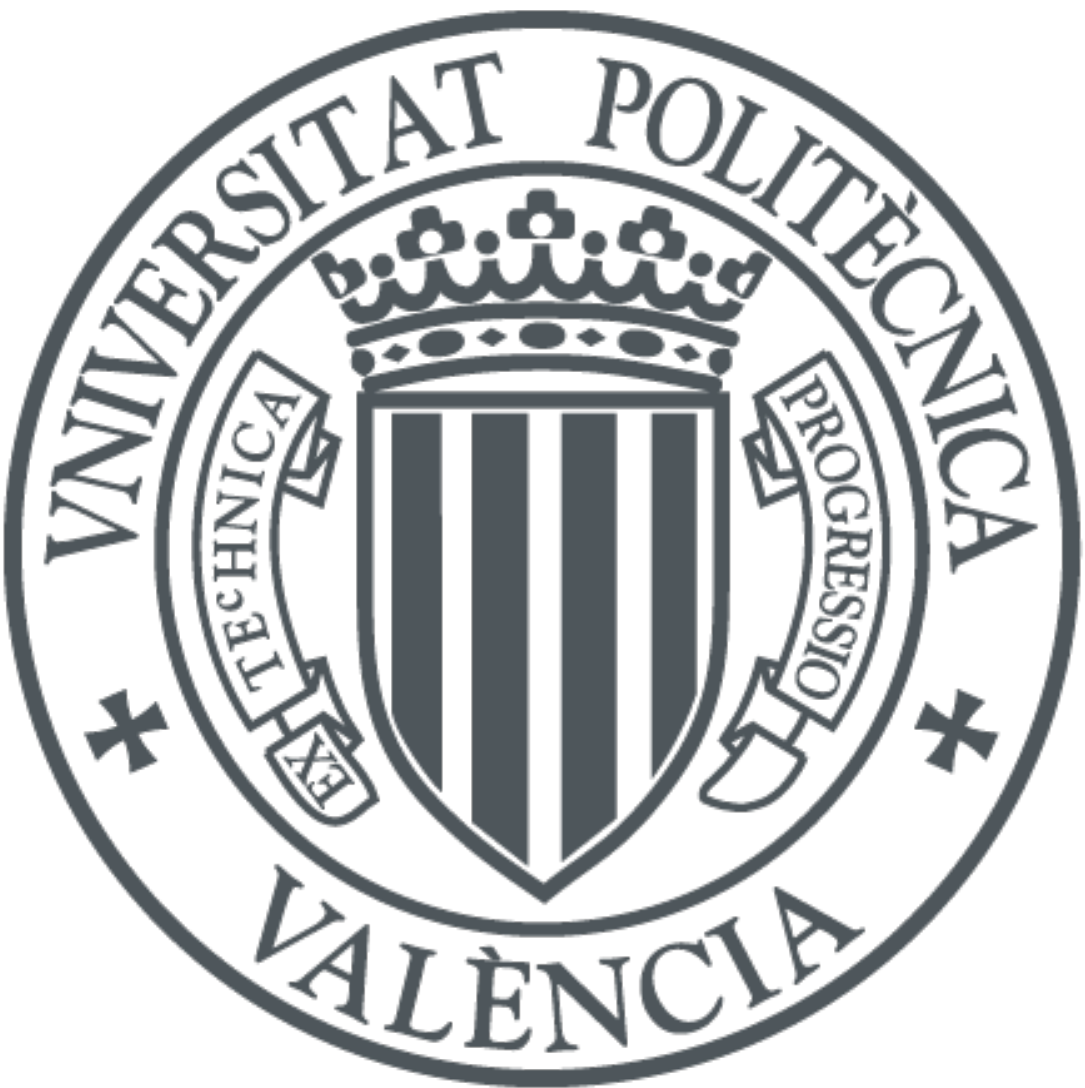

The final publication is available at

http://doi.org/10.1016/j.ijpe.2012.03.028

Copyright Elsevier

Additional Information 


\title{
Economical and technological study of surface grinding versus face milling in hardened AISI D3 steel machining operations.
}

\author{
AUTHORS: Carlos Vila ${ }^{\mathrm{a}, *}$, Hector R. Siller ${ }^{\mathrm{b}}$, Ciro A. Rodriguez ${ }^{\mathrm{b}}$, Gracia M. Bruscas ${ }^{\mathrm{a}}$ \\ and Julio Serrano ${ }^{\mathrm{a}}$
}

ABSTRACT: This work deals with the technological and economic considerations required to select face milling vs. surface grinding operations in the manufacture of hardened steel flat surfaces for dies and moulds. In terms of technological considerations, factors such as component geometry, material and surface quality (dimensional tolerance and surface finish) are taken into account. The economic considerations include the cost of machine depreciation, labour and consumables (cutting tools in face milling vs. grinding wheels and dressing tool in surface grinding). A case study is presented based on the prismatic components in ceramic tile moulds and their associated manufacturing operations. Surface grinding and face milling experimentation was conducted on cold work steel AISI D3 (with hardness of 60 HRC) with aluminium oxide grinding wheels and coated tungsten carbide cutting tool, respectively. Technological attributes and economics of face milling are compared with surface grinding of this type of mould components. The main conclusion is that face milling with chamfered edge preparation in coated tungsten carbide tools is a competitive process, compared with surface grinding, in terms of product quality and economics.

Keywords: high performance machining, hardened steel, face milling, surface grinding, process planning. 


\section{AFFILIATIONS:}

a Dept. of Industrial Systems Engineering and Design,

Universitat Jaume I.

Address: Av. Sos Baynat s/n

Castellón 12071 SPAIN.

*Corresponding author: vila@esid.uji.es

Tel.:+34-964-729126.

Fax:+34-964-728170

${ }^{\mathrm{b}}$ Center for Innovation in Design and Technology,

Tecnológico de Monterrey

Address: Av. Eugenio Garza Sada \#2501 Sur

Monterrey 64849 MÉXICO

Tel.: +52 (81) 81582056 


\section{Introduction}

\section{1. Motivation}

The High Speed Machining (HSM) technology is now redefined as High Performance Machining (HPM) (Arnone, 1998) to incorporate high accuracy and dynamic performance of the machines. HPM has been widely used in the manufacturing of aluminium aeronautical and automotive components. In the last decade, this process is being increasingly used in the manufacturing of dies and mould with hardened steels (30$62 \mathrm{HRC})$, especially in die casting, plastic injection and forging industries. Advantages of HPM over hardened steels, in terms of productivity and quality, are well documented in literature (Fallbohmer et al., 2000; Altan et al., 2001; López de Lacalle et al., 2002).

The traditional way of manufacturing parts with hardened steels begins with milling the work piece in the annealed state before heat treatment. Next, finishing processes as electro discharge machining, grinding and manual polishing are performed to achieve the specified geometries and surface qualities. It has been demonstrated that, by selecting the appropriate cutting parameters and cutting tools, finishing HPM operations can be performed after heat treatment and therefore, manufacturing routes can be shortened. By adopting HPM technology, lead times and costs can be reduced significantly, and companies can successfully challenge the competitive market of tooling.

The objective of this work is to compare HPM operations against other traditional ones in order to achieve more economical products. The nomenclature used during this research is shown in Table 1 to make easy to the readers follow the proposal. 


\begin{tabular}{|c|c|}
\hline Symbol & Description \\
\hline HSM & High Speed Machining \\
\hline HPM & High Performance Machining \\
\hline EDM & Electro Discharge Machining \\
\hline $\mathrm{HRC}$ & Hardness Rockwell C \\
\hline AISI & American Iron and Steel Institute \\
\hline AISI D3 & $\begin{array}{l}\text { AI SI Type D3 / JIS SKD1 / DI N 1.2080 / UNS T30403 / ASTM A681 / } \\
\text { FED QQ-T-570 / SAE J } 437 \text { (D2) / SAE J } 438 \text { (D2) } \\
\text { High-carbon, high-chromium steel. Virtually no deformation during } \\
\text { hardening. High wear resistance which increases with C and V } \\
\text { content. } \\
\text { Tool Steel, oil-quenched from } 980^{\circ} \mathrm{C}\left(1800^{\circ} \mathrm{F}\right) \text {, tempered at } 200^{\circ} \mathrm{C}\end{array}$ \\
\hline AlSI D2 & $\begin{array}{l}\text { Al SI Type D2 / UNS T30402 } \\
\text { High carbon, high chromium. } \\
\text { Tool Steel, air-quenched from } 1010^{\circ} \mathrm{C} \text {, tempered from } 200^{\circ} \mathrm{C} \text { to } \\
450^{\circ} \mathrm{C} \text {. }\end{array}$ \\
\hline AISI D6 & AISI D6 / DIN 1.2436. Tool steel, mould steel, die steel \\
\hline WC & Wolframium (Tungsten) Carbide \\
\hline $\mathrm{CBN}$ & Cubic Boron Nitride \\
\hline CAM & Computer Aided Manufacturing \\
\hline CNC & Computerized Numerical Control \\
\hline$T_{G}$ & Total Grinding Time per lot \\
\hline$T_{M}$ & Total Machining Time per lot \\
\hline Ts & General Production System Time per lot \\
\hline$T_{p}$ & Productive Time \\
\hline$T_{n p}$ & Non Productive Time \\
\hline $\mathrm{Pu}_{\mathrm{u}}$ & System Unit Productivity \\
\hline Q & Material removed rate \\
\hline$r_{\mathrm{np}}$ & Non Productive Time ratio \\
\hline Cs & General Cost \\
\hline $\mathrm{C}_{\mathrm{Mi}}$ & Machining Cost for i \\
\hline $\mathrm{C}_{\mathrm{Gi}}$ & Grinding Cost for i \\
\hline Dc & Cutting diameter \\
\hline $\mathrm{V}_{\mathrm{c}}$ & Cutting speed for machining \\
\hline $\mathrm{F}$ & Feed rate $(\mathrm{mm} / \mathrm{min})$ \\
\hline$a_{e}$ & Radial cutting depth (mm) \\
\hline$a_{p}$ & Axial cutting depth (mm) \\
\hline $\mathrm{V}_{\mathrm{s}}$ & Cutting speed for grinding \\
\hline $\mathrm{R}_{\mathrm{a}}$ & Arithmetical mean roughness $(\mu \mathrm{m})$ \\
\hline VB & Tool flank wear $(\mu \mathrm{m})$ \\
\hline
\end{tabular}

Table 1. Nomenclature in order of apearance.

\section{2. Related Work}

In the manufacture of die and mould components, a variety of cutting tools and operations are utilized, as shown in Fig.1. Studies regarding HPM on hardened steels have been concentrated mainly in profile milling and sculptured surface milling operations (Fallbohmer et al., 2000; Urbanski et al., 2000; Altan et al., 2001; López de Lacalle et al., 
2002; Coldwell et al., 2003; Krajnik and Kopac, 2004; Vivancos et al., 2004; Iqbal et al., 2006).

Studies of face milling in hardened steels are more limited. Aslan (Aslan, 2006) studied face milling of AISI D3 (JIS SKD1 / DIN 1.2080) steel at 62 HRC and found that the best cutting performance in terms of flank wear and surface finish was reached by polycrystalline cubic boron nitride insert tools (Pc-BN), which were capable of removing material volume of $65 \mathrm{~cm}^{3}$ and generated a surface finish of $R_{a}$ between 0.3 and $3 \mu \mathrm{m}$, for a flank wear up to $300 \mu \mathrm{m}$.

In the same work, ceramic tools specifically made of aluminum oxide $\left(\mathrm{Al}_{2} \mathrm{O}_{3}\right)$ and TiCN (mixed ceramics), were capable of removing less material volume $\left(8 \mathrm{~cm}^{3}\right)$ and reaching a surface finish of $R_{a}$ between 1.3 to $3 \mu \mathrm{m}$, for a flank wear up to $300 \mu \mathrm{m}$, but their cost is about five or six times cheaper than $\mathrm{cBN}$. The choice of other pure ceramic tools like $\mathrm{Si}_{3} \mathrm{~N}_{4}$ is not recommended for face milling (i.e. some experimental works report catastrophic failures due to the chemical affinity with hardened steel and a lower hardness in comparison with $\mathrm{Al}_{2} \mathrm{O}_{3}$ ) [Liu, 2002].”

Koshy, Dewes and Aspinwall (Koshy et al., 2002) tested face milling of AISI D2 at 58 HRC with cBN tools and found acceptable tool life together with excellent surface finish in the range of 0.1 to $0.2 \mu \mathrm{m}$ in $\mathrm{R}_{\mathrm{a}}$. However, the tools failed by fracture of the cutting edge and the authors concluded that for generating flat surfaces in hardened D2 material. In addition, authors indicate the need for longer tool life would in order to make the process economically viable.

Braghini and Coelho (Braghini and Coelho, 2001) tested c-BN tools to face mill AISI D6 steel at $58 \mathrm{HRC}$, removing $15 \mathrm{~cm}^{3}$ of material with $300 \mu \mathrm{m}$ of tool wear. In this case, surface finish was between 0.2 and $0.3 \mu \mathrm{m}$ in $\mathrm{R}_{\mathrm{a}}$. Nevertheless, graphs presented in the 
work show scattered points that prevent to state strong conclusions about surface quality and productivity.
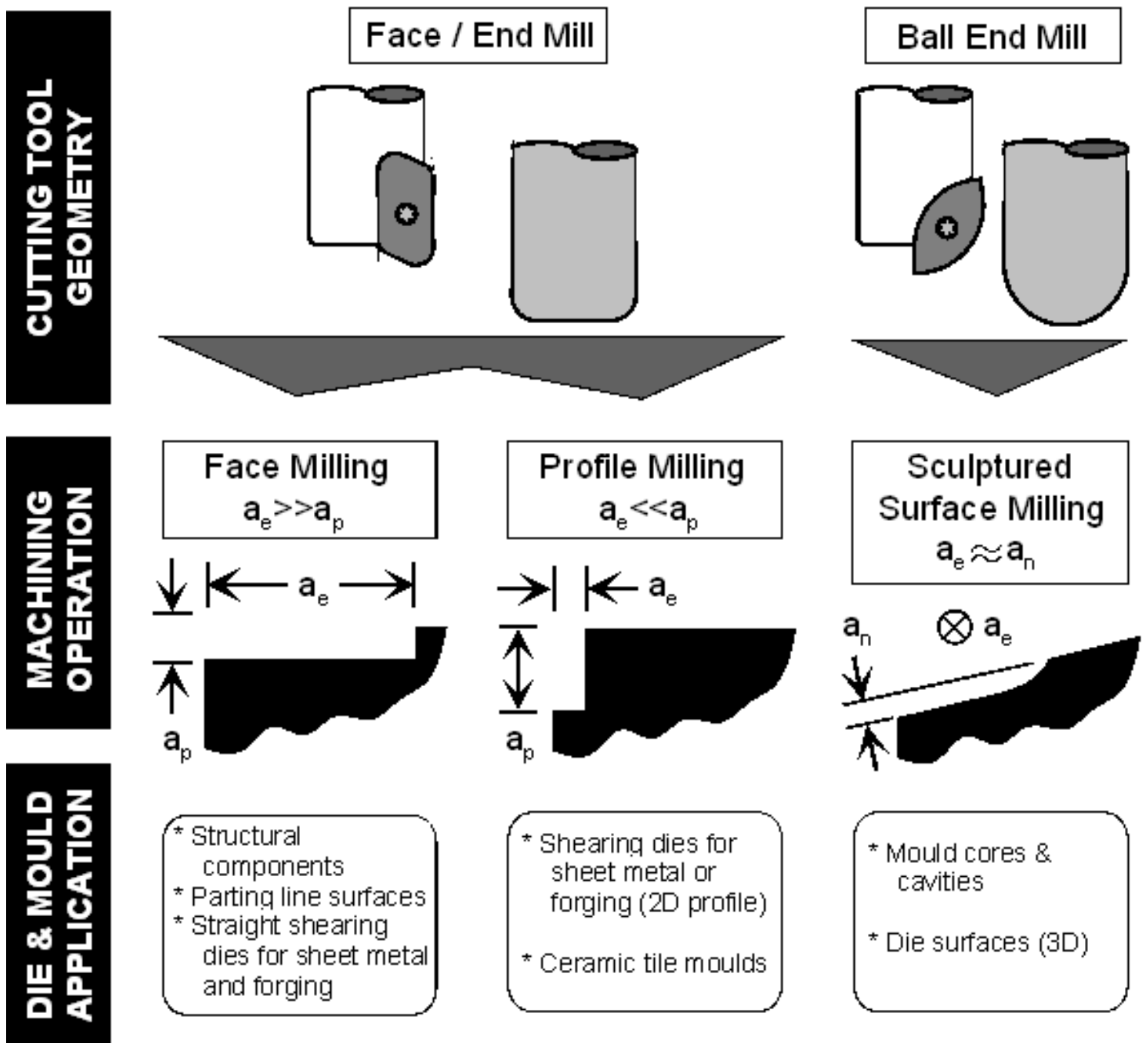

Fig.1. Cutting tool geometry, machining operations and their respective application in die and mould component manufacturing.

There are only few papers found in literature which explore the economics of high performance manufacturing processes in the moulds and dies industry. Alam, Lee, Rahman and Sankaran (Alam et al., 2002) developed a decision algorithm as a help to choose when to use electro discharge machining (EDM) or High Performance Machining 
(HPM) depending of variables such material hardness and surface finish required. Also, costs of these processes in the manufacturing of injection moulds have been analysed. Nevertheless, the algorithm is more suitable to process combinations of EDM and HPM and applies to particular types of cavities, considering some limitations and external factors.

In regards to manufacturing process for hardened steels, there are a number of studies that compare the technical and economic capabilities of grinding vs. hard turning (Brinksmeier et al., 1998; Klocke et al., 2005), as shown in Fig. 2. When comparing HPM vs. surface grinding for hardened steels, similar criteria as those shown in Fig.2 should be used. However, an economic assessment of HPM vs. surface grinding, in the context of die and mould manufacture, is not available in the relevant literature.

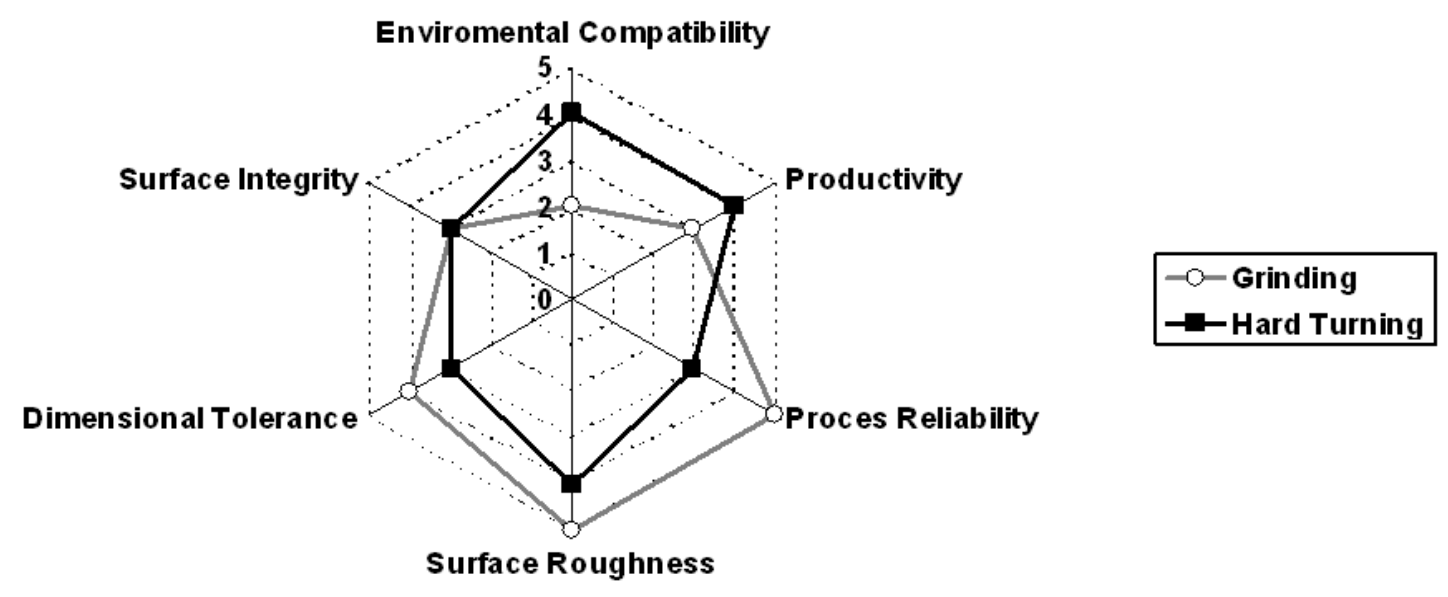

Fig.2. Capability comparison between hard turning and cylindrical grinding (adapted from Klocke 2005).

López de Lacalle, Lamikiz, Salgado, Herranz and Rivero (López et al., 2002), provide some guidelines for the process planning for reliable HPM of moulds, and compare this process with EDM taking in account CAM programming, processing times and surface 
quality. The guidelines are dependent on CAM strategies for finishing operations with ball nose end mills and do not apply to other kinds of finishing operations.

As we can see there is a need of developing a cost model in order to evaluate the economic implications of process planning in mould and die manufacturing. The literature shows an evolution of cost models applied to metal working that can help the process planning activity (Abdel-Malek \& Asadathorn, 1996), that considered the influence of the process and machine tool selection in part tolerances and allowances. The present work was based on activity-based cost models proposed by Ben-Arieh and Qian (Ben-Arieh and Qian, 2003; Qian and Ben-Arieh, 2008) and Özbayrak (Özbayrak, 2004). These models allow determining the cost but do not help in decision making when alternative processes can be selected and parameters can change the cost of an operation and, therefore, the global cost.

We can also find works about general cost models that can be applied or adapted to our specific case of die and mould manufacturing. For example, Cavalieri (Cavalieri et al., 2004) made a comparison between parametric and artificial intelligent models for the estimation of manufacturing costs for mechanical manufacturing of a specific automotive iron part. They developed a generic cost model that included fixed cost, scrap rates and manufacturing operation cost. The values of the coefficients of the models are determined with the help of artificial neural networks that requires huge amount of training data.

More recently, another work established a cost model including the relations between the specification of the manufacturing features and the engaged costs of the manufacturing operations (H’mida, 2006).

However, one of the most suitable works for our purpose is the contribution of Jönsson (Jönsson et al., 2008) that described, in a generic model, the influence of 
technical factors on the manufacturing cost for a deterministic product development. The model gives some insights about a real scenario of manufacturing decision-making subject to organisational disturbances.

Another contribution that supports our work is the applied cost analysis perspective of Folgado (Folgado et al., 2010), that compared by cost analysis two manufacturing processes for mould manufacturing, one based on high speed machining technology and the other based on a spray metal tooling (SMT) technology. The main finding of this work is that the later technology can be a sustainable solution for short batch parts because its initial investment cost. However, according to the cost model developed, for larger production volumes High Speed Machining is the best solution. The authors performed their analysis in aluminium moulds but in the tooling industry the most used moulds are made of hardened steel.

\section{3. Objective}

The objective of this study is to develop selection criteria, based on industrial practice and experimentation with state-of-the-art machining technology, to support process planning in terms of selecting face milling vs. surface grinding for manufacture of hardened steel flat surfaces in dies and moulds. The following sections show the proposed methodology and a case study associated to ceramic tile moulds with hardened AISI D3 steel components with a hardness of 60 HRC.

\section{Methodology}

Due to a better heat dissipation and lower cutting forces, HPM is a process with higher material removal rates, higher surface quality and more geometrical precision in comparison with the traditional machining processes. The evolution of tool and machine 
design and construction technologies has allowed increasing certain parameters (Table 2). This However, HPM faces significant challenges in terms of tool life and potential changes in workpiece surface layer properties (Fallbohmer et al., 2000). Nevertheless, tool rooms which establish this process successfully in their manufacturing routes will have shorter cycle times and, therefore, will react faster to market demands. In order to aid the decision making of process planners, the following sections include technological and economic considerations that must be taken into account for process selection for the flat surface finishing of dies and moulds.

\begin{tabular}{|c|c|c|}
\hline Manufacturing Process & \multicolumn{2}{|l|}{ Machining } \\
\hline Operation & \multicolumn{2}{|c|}{ General milling operation for hardened steels } \\
\hline Tool & \multicolumn{2}{|l|}{ End Mill } \\
\hline Material & \multicolumn{2}{|l|}{ AISI D2 60 HRC } \\
\hline PARAMETERS & TRADITIONAL & HIGH PERFORMANCE \\
\hline Speed & $900 \mathrm{rpm}$ & up to $10,000 \mathrm{rpm}$ \\
\hline Cutting speed & $\begin{array}{l}20 \mathrm{~m} / \mathrm{min} \\
\text { (up to } 100 \mathrm{~m} / \mathrm{min} \text { ) }\end{array}$ & $\begin{array}{l}70 \mathrm{~m} / \mathrm{min} \\
\text { (up to } 500 \mathrm{~m} / \mathrm{min} \text { ) }\end{array}$ \\
\hline Chip load & up to $0.2 \mathrm{~mm} /$ tooth & up to $0.5 \mathrm{~mm} /$ tooth \\
\hline Radial Depth of Cut & Dc & $<0.5 \cdot \mathrm{Dc}$ \\
\hline Axial Depth of Cut & 0.4 Dc & Dc \\
\hline Tolerances & $50 \mu \mathrm{m}$ & $20 \mu \mathrm{m}$ \\
\hline $\mathbf{R}_{\mathbf{a}}$ & $3 \mu \mathrm{m}$ & $0.1 \mu \mathrm{m}$ \\
\hline
\end{tabular}

Table 2. Comparative of typical values of parameters for hardened steels (Koshy, 2002; Coldwell et al., 2003; Toh, 2006; Ciurana et al., 2008).

\section{1. Technological Considerations}

Often, decisions regarding the selection of the most appropriate process (grinding or HPM) for mold manufacturing are based on the experience of individuals. Several parameters and constraints that influence the selection can be found or are mentioned in 
literature, catalogues or even in industry know-how, but there are no standard rules or guidelines to help in this selection process.

The main considerations should be the following:

- Mould material. Material hardness is one of the most important selection parameters when deciding what manufacturing process to use. Grinding can be used with all materials, excluding soft or gummy materials (Bralla, 1999; Swift and Booker; 2001). Although HPM has a more limited applicability, documented studies show that all kinds of tool geometries (ball end mill, toroidal end mill, end mill and face mill) can be applied on tools steels up to a hardness of 60-62 HRC.

- $\quad$ Mould component geometry. In general, intricate and complex geometries in mould cavities, as well as sharp internal corners or internal corners with small radii can be very difficult or even impossible to obtain either with grinding or HPM. In those cases, other alternatives such as EDM should be considered. The scope of this study is limited to prismatic components with flat surfaces and 2D profiles in hardened tool steel. For these component geometries, the use of grinding or HPM becomes appropriate. Grinding has more limitations in relation to complex geometries and profiles than HPM. There are some other die and mould geometry elements that will influence decision making. The need of high length to diameter (L/D) ratios will lead to poor tool performance due to stiffness and run-out problems. It is generally preferable the use of tools with as small $\mathrm{L} / \mathrm{D}$ ratio as possible. Access to the different surfaces to be machined must also be taken into account, since the surface grinding process requires an open surface. For machining a given 2D profile, only HPM is a viable process. There might be restrictions when manufacturing parts 
are difficult to position and hold in the machine. Since cutting forces for grinding are lower, holding might be easier in this case.

- Geometrical tolerance \& surface finish. Finally, important issues are the required geometrical tolerance and surface finish. According to the literature, up to $0.008 \mathrm{~mm}$ in flat capability (Wright, 2001) and surface finish $\mathrm{R}_{\mathrm{a}}$ between 0.025 and 1.6 $\mu \mathrm{m}$ (Bralla, 1999, Swift and booker, 2001) are possible depending on the type of abrasive machining process. With HPM, some works show that surface finish $\mathrm{R}_{\mathrm{a}}$ between $0.15 \mu \mathrm{m}$ and $6 \mu \mathrm{m}$ can be obtained, in sculptured milling operations (Urbanski et al., 2000; Vivancoset al., 2004; Koshy et al., 2002, Alam et al., 2002), $\mathrm{R}_{\mathrm{a}}$ between 0.4 and $1.4 \mu \mathrm{m}$ in profile milling operations (Iqbal et al., 2006), and $\mathrm{R}_{\mathrm{a}}$ between and 0.2 to $3 \mu \mathrm{m}$ in face milling operations (Braghini and Coelho, 2001; Koshy et al., 2002; Aslan, 2006).

- Tool Material. Typical tool materials for machining tool steels are coated WC, cermet, ceramics and cBN (Koshy et al., 2002; Krajnik and Kopac, 2004). Depending on the application, geometric features, type of operation (profiling, face milling, contouring) and other variables, some tool materials are more suitable than others. For example, cBN cutting tools are not suitable for intermittent profiling because they can suffer catastrophic failure. In comparison, WC cutting tools present shorter tool life but their wear is progressive and can be better controlled at medium cutting speeds (Dogra et al., 2011).

\section{2. Focus on Flat Surfaces in Hardened Tool Steel}

Based on the scope of this study, from the range of machining operations provided by HPM, the work is focused only on face milling operations. Based on geometrical constraints, the choice of grinding, milling or a combination of both is only applicable in 
the case of flat surface on die and mould components. Therefore, process alternatives and case studies will be focused only on flat surfaces in hardened tool steels for the rest of the discussion in this article.

Once the material and mould component geometry indicate that machining and grinding are applicable, the next deciding factor is quality (geometrical tolerance and surface finish). Based on the collected literature (Bralla, 1999, Swift and Booker, 2001, Webster, 2005), Fig. 3 shows the three different ranges of surface roughness and the recommended process for flat surface on hardened tool steels. For relatively rough finish $\left(R_{a}>1 \mu m\right)$, machining is the process of choice $\left(R_{a}>1 \mu m\right)$. For relatively fine surface finish $\left(\mathrm{R}_{\mathrm{a}}<0.2 \mu \mathrm{m}\right)$, grinding is the process of choice. For the range of $\mathrm{R}_{\mathrm{a}}$ between 0.2 and $1 \mu \mathrm{m}$, there are three viable options: grinding only, machining only, and a combination of machining and grinding.

The specific selection will depend on the process economics (cost and productivity), which in turn will depend on a number of factors (Fig. 3). More details about the interaction of these factors will be described in the following sections. 


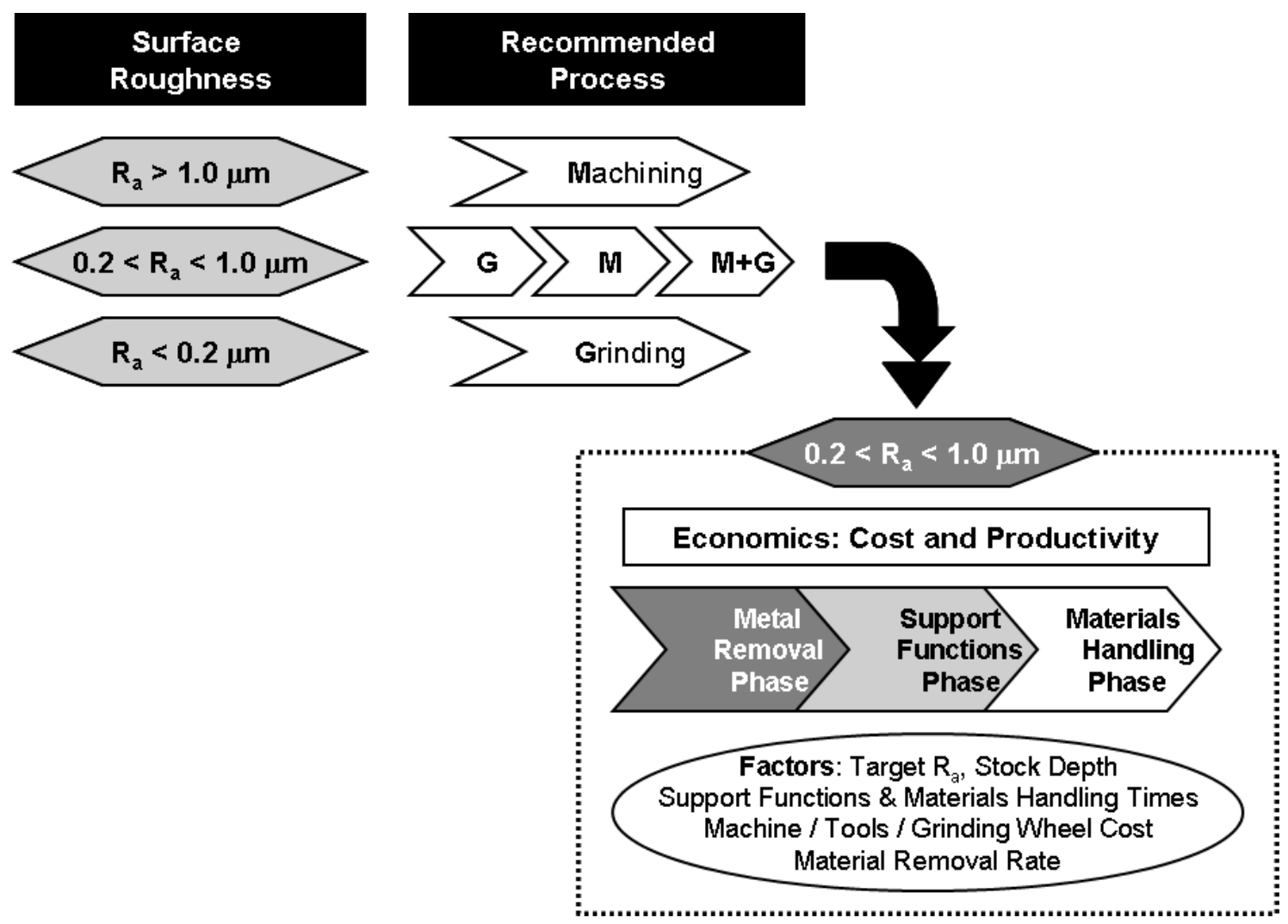

Fig. 3. Recommended processes as a function of surface roughness for flat surfaces on hardened tool steels.

\section{3. Economic Considerations - Productivity and Cost Analysis}

The development of the macro process plan for this case has allowed the definition of some alternatives (Fig.4). The figure shows the process plan alternatives for flat surfaces on hardened steel and a surface roughness range $\mathrm{R}_{\mathrm{a}}$ between 0.2 to $1.0 \mu \mathrm{m}$. For each type of process, and associated machine tool, the operations are classified into:

- The Material Removal Phase involves the actual contact between cutting tool / grinding wheel and mould component metal. The material removal phase is the only one that will impact the productive times.

- The Support Functions Phase aggregates all those functions needed at the machine for production, but without actual material removal. Examples of support functions 
include tool changes, grinding wheel redressing and machine setup. All CNC programs require non-cutting motions for tool/grinding wheel positioning. These motions are part of the non-productive times. Besides, process disturbances and other activities are included in this phase in order to simplify the model.

- The Materials Handling Phase includes workpiece load/unload and on line inspection. These functions also add up to the non-productive times.

The relative cost and productivity of the different phases in machining and/or grinding will determine the best process for a given case. Oversimplified analysis should be avoided, especially in regards to the consideration of more advanced and expensive technology in cutting tools / grinding wheels and machines. There are several documented studies that show how the use of more advanced expensive cutting tools / grinding wheels and machines result in a lower unit cost once the complete system is assessed (Rowe and Morgan, 2004).

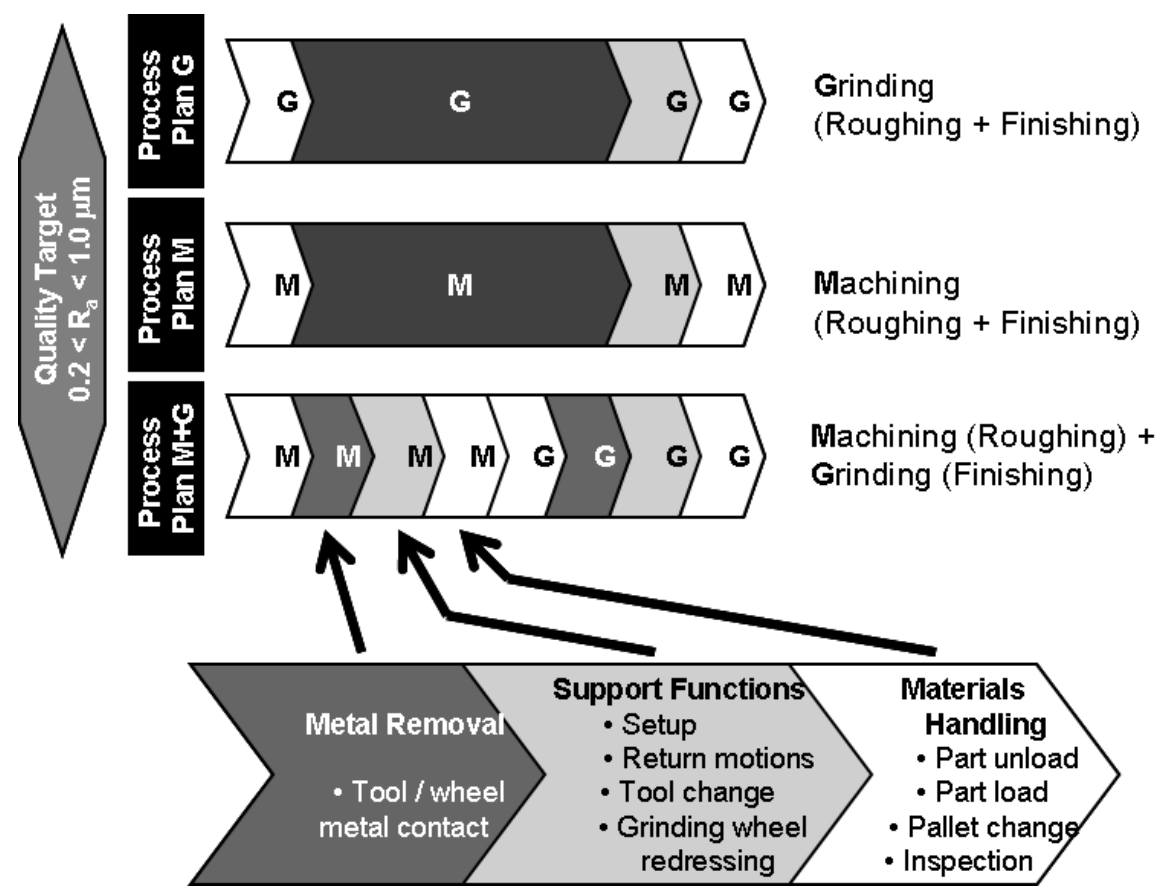

Fig. 4. Process plan alternatives for flat surfaces on hardened steel and a surface roughness range $R_{a}$ between 0.2 to $1.0 \mu \mathrm{m}$. 
In terms of productivity, for the three processes plans shown in Figure 2.2, the general production system time $\left(\mathrm{T}_{\mathrm{S}}\right)$ per lot, is composed of the sum of total machining time $\left(\mathrm{T}_{\mathrm{M}}\right)$ and total grinding time $\left(\mathrm{T}_{\mathrm{G}}\right)$, as expressed in equation (1):

$$
T_{S}=T_{M}+T_{G}
$$

For each term of this sum, productive and non-productive parameters have been defined in order to obtain an equation that will consider the type of operation. The factors related to productive and non-productive times in machining and grinding are defined in Table 3.

\begin{tabular}{|c|l|l|}
\hline & \multicolumn{1}{|c|}{ Machining } & \multicolumn{1}{c|}{ Grinding } \\
\hline Productive Time, & $\mathrm{t}_{\mathrm{RM}}$ : Roughing operation time & $\mathrm{t}_{\mathrm{RG}}:$ Roughing operation time \\
\cline { 2 - 3 } $\mathrm{T}_{\mathrm{p}}$ & $\mathrm{t}_{\mathrm{FM}}$ : Finishing operation time & $\mathrm{t}_{\mathrm{FG}}$ : Finishing operation time \\
\cline { 2 - 3 } & $\mathrm{N}_{\mathrm{W}}$ : Number of parts per lot & $\mathrm{N}_{\mathrm{Wp}}$ : Numbers of parts per lot \\
\hline $\begin{array}{c}\text { Non-productive Timee } \\
\mathrm{T}_{\mathrm{np}}\end{array}$ & $\mathrm{T}_{\mathrm{LM}}$ : Setup per lot & $\mathrm{T}_{\mathrm{LG}}$ : Setup per lot \\
\cline { 2 - 3 } & $\mathrm{T}_{\mathrm{HM}}$ : Workpiece handling per lot & $\mathrm{T}_{\mathrm{HG}}$ : Workpiece handling per lot \\
\cline { 2 - 3 } & $\mathrm{T}_{\mathrm{TcM}}$ : Tool change per lot & $\mathrm{T}_{\mathrm{WGG}}$ : Tool change per lot \\
\hline
\end{tabular}

Table 3. Factors related to the productive and non-productive time

Once defined these parameters and in order to consider the combination of machining and grinding, each separate process is defined with a roughing and finishing component as expressed in equations (2) and (3),

$$
\begin{aligned}
& T_{M}=\left(p_{1} \cdot t_{R M}+p_{2} \cdot t_{F M}\right) \cdot N_{W p}+p_{1}\left(T_{L M}+T_{H M}+T_{T C M}\right) \\
& T_{G}=\left(p_{3} \cdot t_{R G}+p_{4} \cdot t_{F G}\right) \cdot N_{W p}+p_{4}\left(T_{L G}+T_{H G}+T_{W C G}\right)
\end{aligned}
$$

The matrix shown in Table 4 indicates the binary factors to generate the different process plans that will customize the expressions 2 and 3. 


\begin{tabular}{|l|c|c|c|c|}
\hline \multirow{2}{*}{ Alternative } & $\begin{array}{c}\text { Rough } \\
\text { Milling }\end{array}$ & $\begin{array}{c}\text { Finish } \\
\text { Milling }\end{array}$ & $\begin{array}{c}\text { Rough } \\
\text { Grinding }\end{array}$ & $\begin{array}{c}\text { Finish } \\
\text { Grinding }\end{array}$ \\
\cline { 2 - 5 } & $\mathbf{p}$ 1 & $\mathbf{p}_{2}$ & $\mathbf{p}$ 3 & $\mathbf{p}$ 4 \\
\hline Process Plan M & 1 & 1 & 0 & 0 \\
\hline Process Plan G & 0 & 0 & 1 & 1 \\
\hline Process Plan M+G & 1 & 0 & 0 & 1 \\
\hline
\end{tabular}

Table 4. Matrix representation of process plan alternatives for flat surfaces on hardened steel and a surface roughness range $\mathrm{R}_{\mathrm{a}}$ between 0.2 to $1.0 \mu \mathrm{m}$.

Another definition is the proportion between productive time $\left(T_{p}\right)$, and nonproductive time $\left(\mathrm{T}_{\mathrm{np}}\right)$. In this work, it is defined in the equation (4) as the non-productive time ratio $\left(\mathrm{r}_{\mathrm{np}}\right)$,

$$
r_{n p}=\frac{T_{n p}}{T_{p}}
$$

During the productive time $\left(\mathrm{T}_{\mathrm{p}}\right)$, there is continuous contact between the cutting tool (grinding wheel) and the metal. Therefore, the material removal rate (volume of material removed in unit time, Q) is defined based on the productive time only. The system unit productivity $\left(\mathrm{P}_{\mathrm{u}}\right)$ is therefore defined in equation (5), based on the material removed rate or based on manufacturing system time $\left(\mathrm{T}_{\mathrm{S}}\right.$ ) per lot and the workpiece material volume $\left(\mathrm{V}_{\mathrm{wp}}\right)$,

$$
P_{u}=\frac{Q}{1+r_{n p}}=\frac{V_{w p} N_{w p}}{T_{S}}
$$

If we define the cost for each tool and manufacturing process depending on the productive and non-productive factors (Table 5), we can express the general cost of the manufacturing system for the entire lot, excluding raw material cost and overhead (Cs), with the following equation:

$$
C_{S}=C_{M P}+C_{G P}+C_{M T}+C_{G T}
$$




\begin{tabular}{|c|l|l|}
\hline & \multicolumn{1}{|c|}{ Machining } & \multicolumn{1}{c|}{ Grinding } \\
\hline $\begin{array}{c}\text { Machine Cost Associated to } \\
\text { Productive and } \\
\text { Non-Productive Time }\end{array}$ & \begin{tabular}{l}
$\mathrm{C}_{\mathrm{MP}}$ : Machining process cost \\
\cline { 2 - 3 }
\end{tabular} & $\mathrm{C}_{\mathrm{MP}}$ : Machining process hourly \\
\hline $\begin{array}{c}\text { Cutting Tool / Grinding } \\
\text { Wheel Wear Cost }\end{array}$ & $\begin{array}{l}\mathrm{H}_{\mathrm{GP}} \text { : Grinding process hourly } \\
\text { rate }\end{array}$ \\
\hline
\end{tabular}

Table 5. Factors related to the machine and cutting tools/grinding wheel cost.

In this equation 6 the machining $\left(\mathrm{C}_{\mathrm{MP}}\right)$ and grinding machine cost $\left(\mathrm{C}_{\mathrm{GP}}\right)$ are calculated considering the total time of the individual operation as it can be seen in equations (7) and (8),

$$
\begin{gathered}
C_{M P}=T_{M} H_{M P} \\
C_{G P}=T_{G} H_{G P}
\end{gathered}
$$

As a result, the proposed economic model for our manufacturing system includes all the cost related to productive and non-productive time (Table 5). The model includes the cost associated to the consumption of cutting tools and grinding wheels considering the overheads of broken tools and damaged edges that implies a slight increment of the edge cost determined by the tool manufacturer. Therefore, in terms of the production facility, the manufacturing system unit cost $\left(\mathrm{C}_{\mathrm{u}}\right)$ is defined in equation (9) as follows:

$$
C_{u}=\frac{C_{s}}{V_{w p} N_{w p}}
$$

The portion of cost due to the associated machine tool can be defined in equation (10) as machining unit cost $\left(\mathrm{C}_{\mathrm{uMP}}\right)$, and in equation (11) as grinding unit cost $\left(\mathrm{C}_{\mathrm{uGP}}\right)$,

$$
C_{u M P}=\frac{H_{M P}}{P_{u}}
$$




$$
C_{u G P}=\frac{H_{G P}}{P_{u}}
$$

The complete unit cost needs to add raw material and administrative overhead. The concepts of System Unit Productivity $\left(\mathrm{P}_{\mathrm{u}}\right)$ and System Unit Cost $\left(\mathrm{C}_{\mathrm{u}}\right)$ are summarized at Fig. 5 as related to the phases of metal removal, support functions and materials handling.

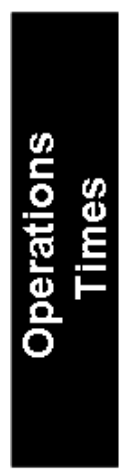

Productive Time, $T_{p}(\min ) \quad$ Non-Productive Time, $T_{n p}(\min )$
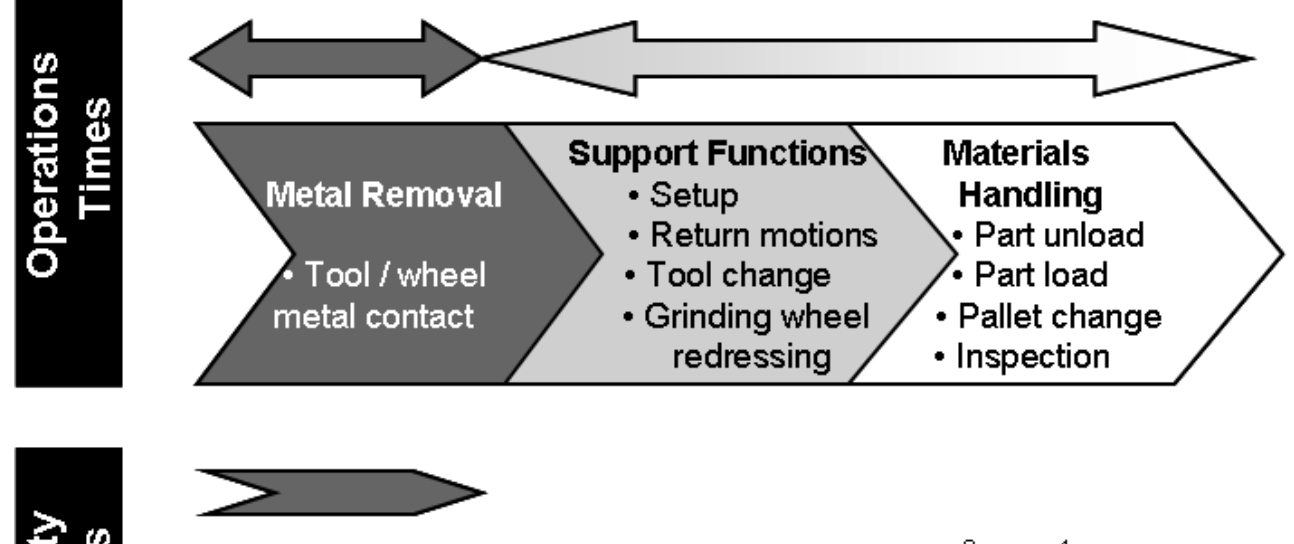

MACHINING: Material Removal Rate, $Q\left(\mathrm{~cm}^{3} \mathrm{~min}^{-1}\right)$ GRINDING: Specific Material Removal Rate, $Q^{\prime}\left(\mathrm{mm}^{3} \mathrm{~mm} \mathrm{~s}^{-1}\right)$

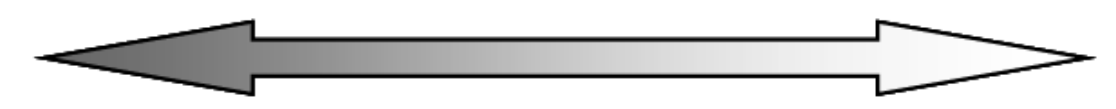

System Unit Productivity, $\mathrm{P}_{\mathrm{u}}\left(\right.$ part $\left.\mathrm{hr}^{-1}\right)$ or $\left(\mathrm{cm}^{3} \mathrm{~min}^{-1}\right)$
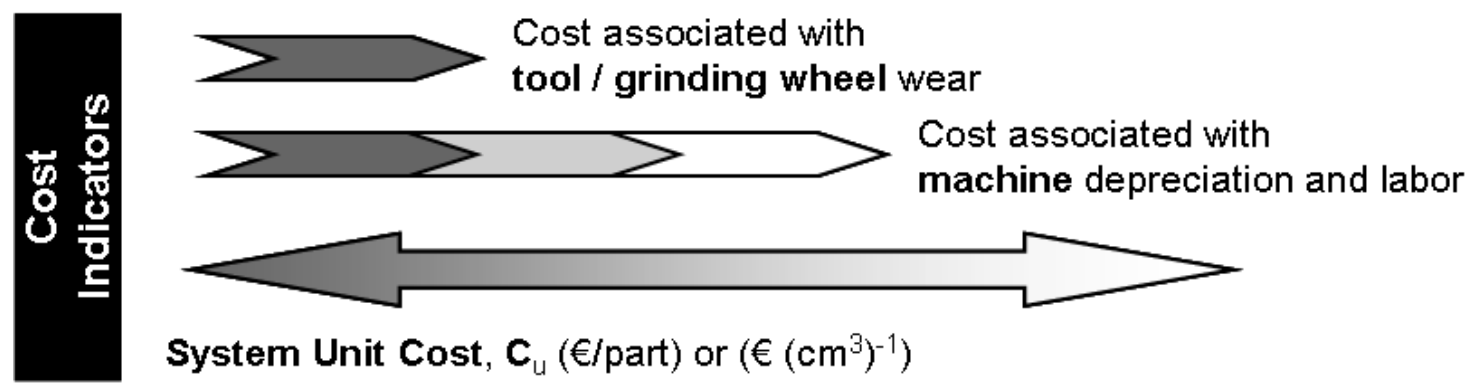

System Unit Cost, $\mathbf{C}_{u}(€ /$ part $)$ or $\left(€\left(\mathrm{~cm}^{3}\right)^{-1}\right)$

Fig. 5. System unit productivity and cost.

\section{4. Experimental Evaluation}

In order to compare technical aspects and process economics, as described in the previous section, there is a need for experimental data (such as cutting tool / grinding wheel 
consumption, material removal rate, etc.) under specific process condition. Cost models such as those of Lee, Rowe and Wang (Rowe and Morgan, 2004, Lee and Shin, 2000, Wang and Liang, 2005) provide more details about those relevant process conditions needed for specifying grinding and machining operations.

In the case of the current study, experimental evaluation was conducted with both surface grinding and face milling (schematically shown in Fig. 6). The face milling process was evaluated using a cutting tool with indexable coated WC inserts, under different machining conditions. The experimental data related to the surface grinding process was collected from an actual mould shop operation. The following sections describe the results from the experimental evaluation and the economic implications of the different process plan alternatives, as described in Fig. 4.

The geometry selected for the experiments was determined by the manufacturer and the setup tried to reply the production environment with the design requirements of tolerances and allowances established by the process planners.
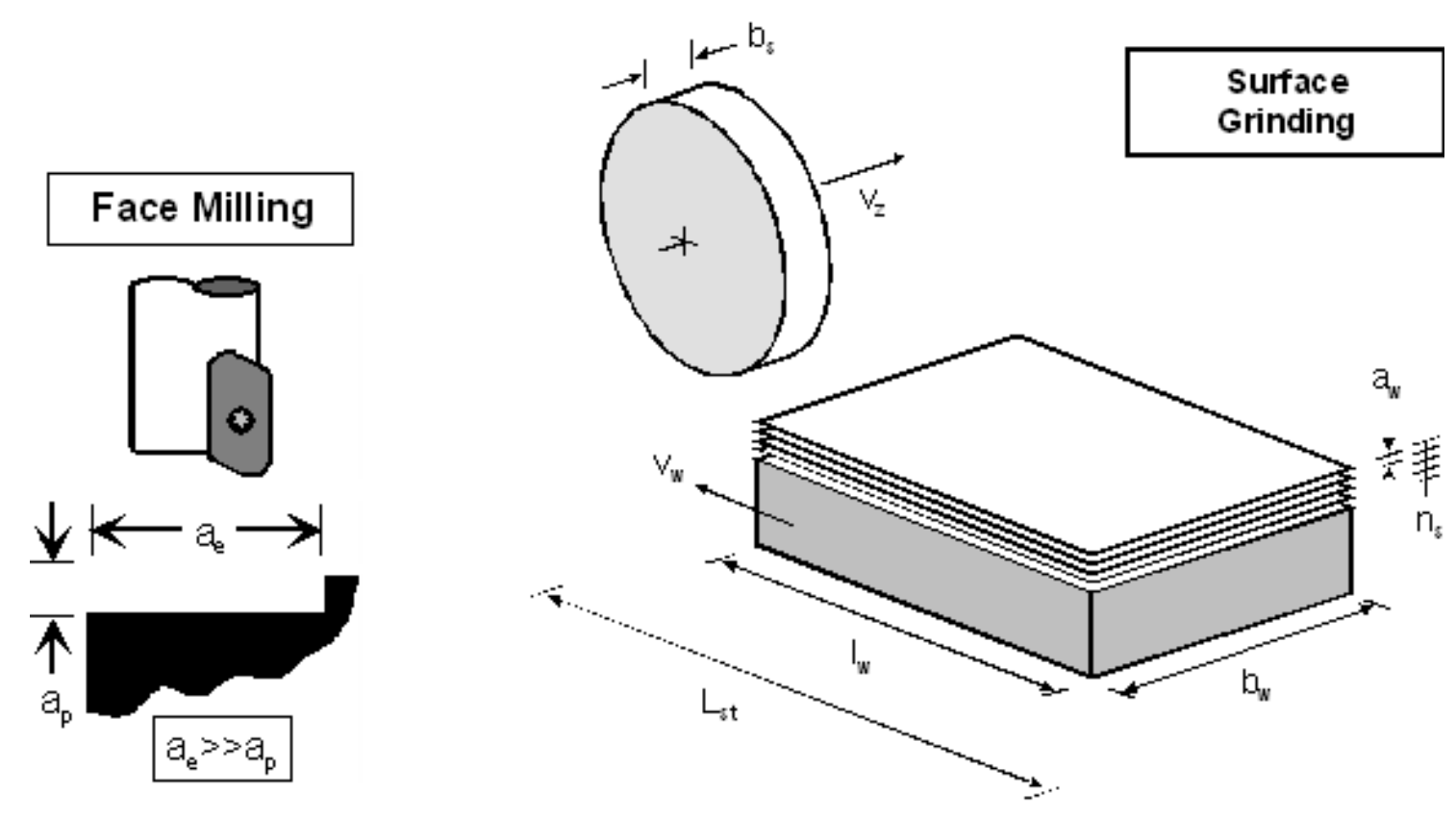
Fig. 6. Experimental evaluations with face milling and surface grinding on hardened tool steel.

\section{Case studies with hardened AISI D3 steel}

The case studies are based on components required for ceramic tile moulds (Vila et al., 2005). This type of moulds requires several prismatic components with hardness of 60 HRC. The following sections deal with the process plan alternatives presented in Fig. 3.

\section{1. Process Plan with Grinding (G)}

The experimental setup is graphically explained in Fig. 7 and it shows the flat surface reciprocating grinding in the context of mould shop operations. All the operation parameters are detailed in the Table 6 . A lot of 12 parts was ground in approximately 240 min. Each part has dimensions of $390 \times 33.5$ x $33.5 \mathrm{~mm}$ and $0.4 \mathrm{~mm}$ of stock removal on the four long sides $\left(21 \mathrm{~cm}^{3} /\right.$ part of workpiece material removed per part). The grinding wheel material is sintered microcrystalline aluminium oxide with vitrified bonding and F370 grit size. The first reason of this selection is that the analysis was conducted through a real case study provided by an industrial company operating in the mould sector. The second reason of this selection is that sintered aluminum oxide abrasives present significant advantages compared to their fused counterparts - particularly in term of life - and are much less expensive than superabrasives. When properly used, sintered abrasives can also result in significantly increased volumetric removal rates, reduced forces and lower work surface temperature during grinding. It is frequently a viable alternative to cBN, particularly in light of the ease of truing and dressing, and the initial wheel cost. (Webster, 2004) 
At a cutting speed $V_{s}$ of $31 \mathrm{~m} \mathrm{~s}^{-1}$, the total workpiece material removed was $252 \mathrm{~cm}^{3}$ for the 12 part lot, while the grinding wheel usage was $48 \mathrm{~cm}^{3}(0.7 \mathrm{~mm}$ of grinding wheel usage in diameter on an average diameter $d_{s}$ of $437 \mathrm{~mm}$ and wheel width $b_{s}$ of $100 \mathrm{~mm}$ ). Therefore, the grinding ratio $G$ was 5.25 on this operation. Under these conditions, the average of surface roughness obtained in surface grinding was $R_{a}$ of $0.30 \mu \mathrm{m}$, close to the expected with the process plan (Fig. 3).

In terms of productivity measures, the part handling and inspection time takes about $50 \%$ of the operation. The non contact grinding wheel motions and redressing take approximately $36 \mathrm{~min}$. for the complete lot. The actual material removal time for the 12 part lot is approximately $84 \mathrm{~min}$. Therefore, the material removal rate $\mathrm{Q}$ is approximately $3 \mathrm{~cm}^{3} / \mathrm{min}$ (specific material removal rate Q' is approximately $0.5 \mathrm{~mm}^{3} \mathrm{~mm}^{-1} \mathrm{~s}^{-1}$ ). All the results in characterization of the flat surface reciprocating grinding are within normal operation parameters of this process as reported in the relevant literature (Webster, 2004.).
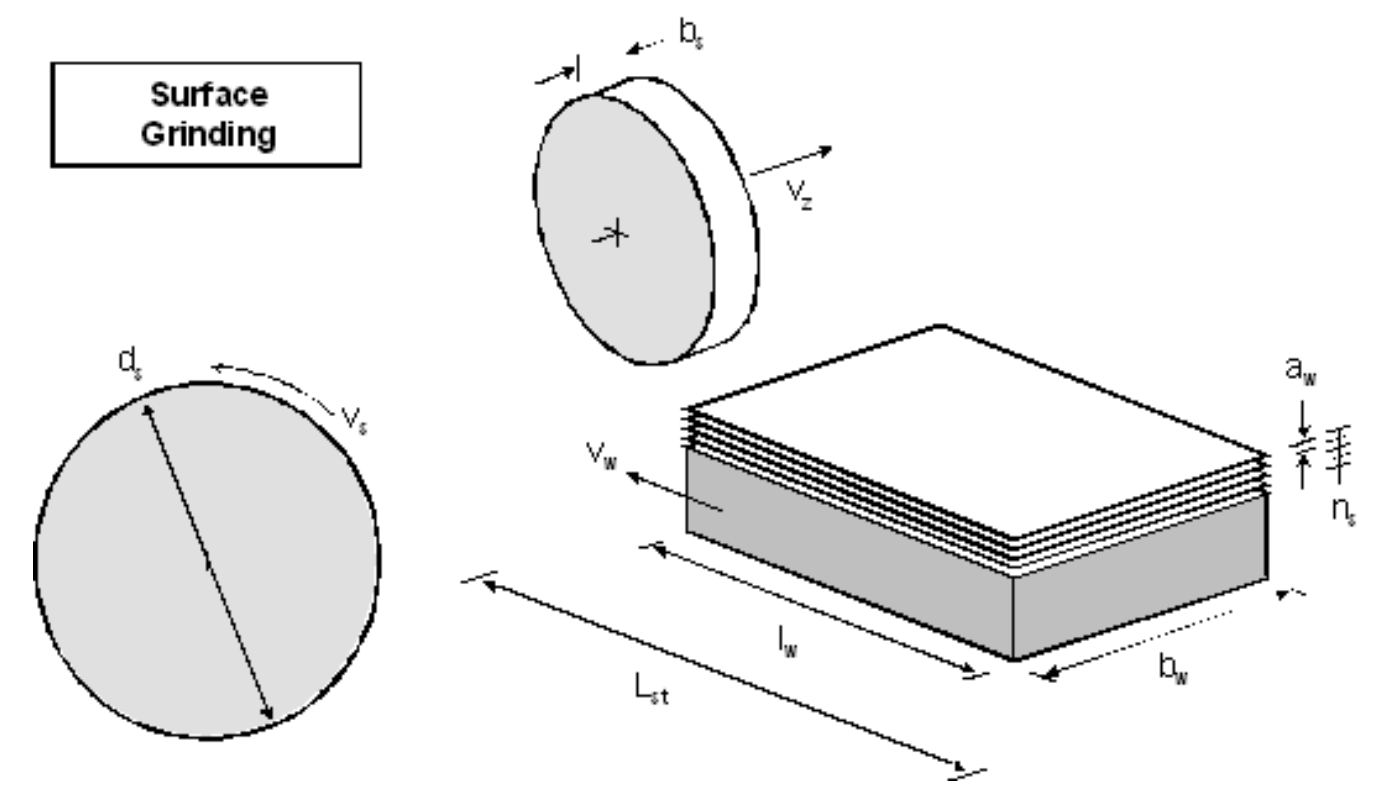

Fig. 7. Experimental setup in flat surface grinding.

\begin{tabular}{|l|l|}
\hline \multicolumn{2}{|c|}{ WORKPIECE } \\
\hline Alloy & AISI D3 / JIS SKD1 / DIN 1.2080 \\
\hline
\end{tabular}




\begin{tabular}{|c|c|}
\hline Hardness & $60 \mathrm{HRc}$ \\
\hline $\begin{array}{l}\text { Number of workpieces } \\
\text { per lot }\end{array}$ & 12 \\
\hline Workpiece geometry & $390 \times 33.5 \times 33.5 \mathrm{~mm}$ \\
\hline \multicolumn{2}{|c|}{ GRINDING WHEEL } \\
\hline ISO Specification & 3SK 370 1H12 VEZ1 \\
\hline Material & Microcrystalline Aluminium Oxide \\
\hline Bond & Vitrified \\
\hline Grit Size & F370 \\
\hline Average diameter & $\mathrm{d}_{\mathrm{s}}=437.5 \mathrm{~mm}$ \\
\hline Width & $b_{s}=100 \mathrm{~mm}$ \\
\hline \multicolumn{2}{|c|}{ CUTTING CONDITIONS } \\
\hline Wheel speed & $\mathrm{V}_{\mathrm{s}}=31 \mathrm{~m} \mathrm{~s}^{-1}$ \\
\hline Transversal feed rate & $\mathrm{V}_{\mathrm{z}}=350 \mathrm{~m} \mathrm{~min}^{-1}$ \\
\hline Workpiece feed rate & $\mathrm{V}_{\mathrm{w}}=14.2 \mathrm{~m} \mathrm{~min}^{-1}$ \\
\hline \multicolumn{2}{|l|}{ Oil-based cooling fluids } \\
\hline \multicolumn{2}{|c|}{ MACHINE TOOL } \\
\hline Model & TRTM2500 DANOBAT \\
\hline Type & Reciprocating grinding machine \\
\hline
\end{tabular}

Table 6. Experimental Fixed Conditions for Process Plan with Grinding (G).

\section{2. Process Plan with Face Milling (M)}

The experimentation was conducted with a double column machining centre suited for mould component manufacturing (the experimental setup is shown in Fig.8 and Table 7). A block of AISI D3 steel (60 HRC) was face milled with successive passes. Detailed measurements of tool wear, surface roughness, and geometrical tolerance, were conducted in order to characterize the process and determine the optimal operation conditions (equipment for measurements is shown in Table 8). After this previous cutting conditions optimizing procedure and according to the surface finish reached in a previous study (Siller et al., 2009) cutting speed was set to $\mathrm{V}_{\mathrm{c}}$ of $75 \mathrm{~m} \mathrm{~min}^{-1}$ and feed per tooth was fixed at $\mathrm{f}_{\mathrm{z}}=0.066 \mathrm{~mm}$. These conditions will assure obtaining tolerances and allowances as the process plan expected previously (Fig. 3). 


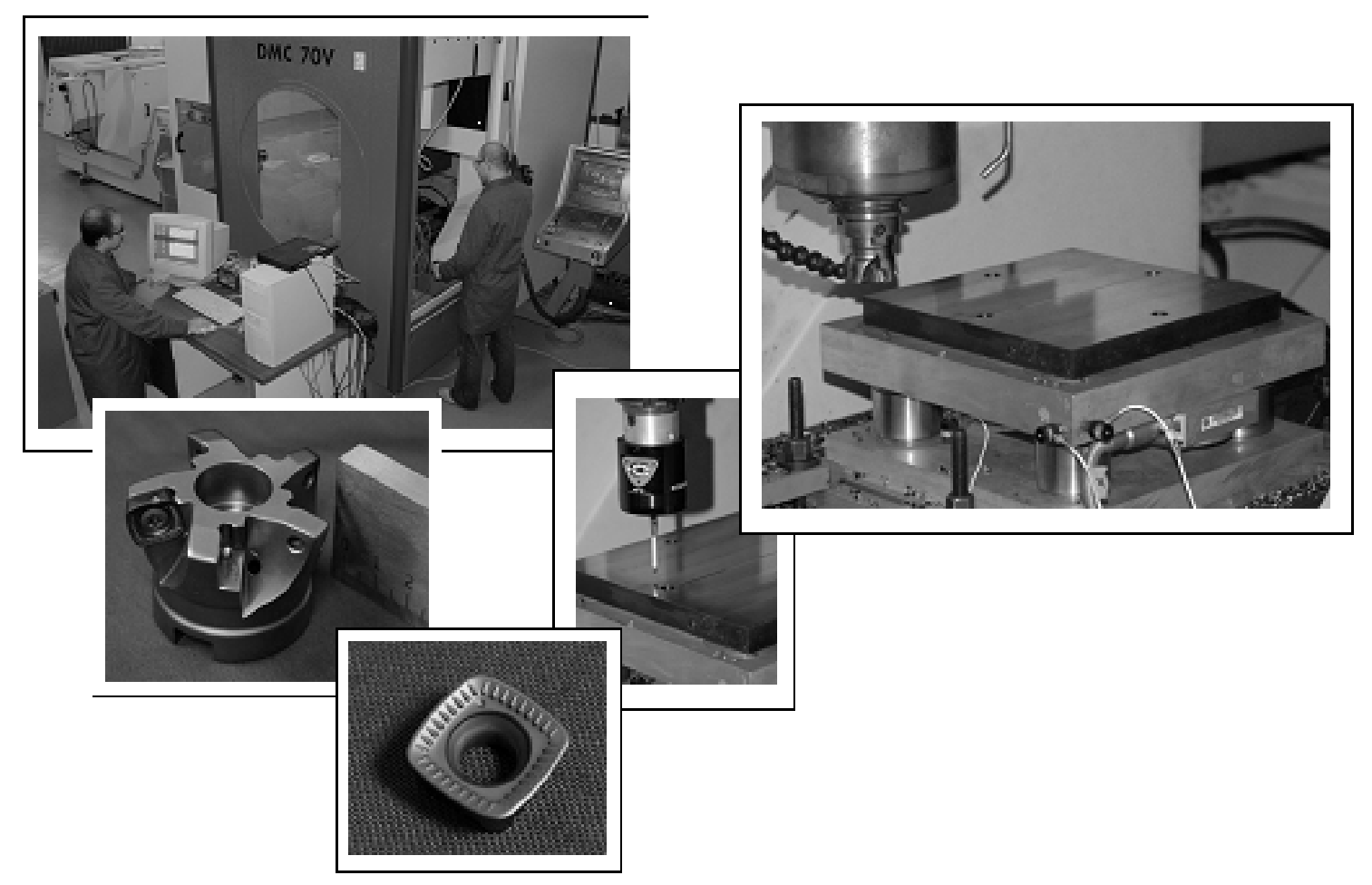

Fig. 8. Experimental setup in face milling. 


\begin{tabular}{|c|c|}
\hline \multicolumn{2}{|c|}{ WORKPIECE } \\
\hline Alloy & AISI D3 / JIS SKD1 / DIN 1.2080 \\
\hline Hardness & $60 \mathrm{HRc}$ \\
\hline Geometry & $250 \times 250 \mathrm{~mm}$ block \\
\hline \multicolumn{2}{|l|}{ CUTTING TOOL } \\
\hline Cutter Type & Face Milling (22 mm bore) \\
\hline Adaptation & BT 40 \\
\hline Overhand Distance & $55.00 \mathrm{~mm}$ \\
\hline Max. Diameter & $52.00 \mathrm{~mm}$ \\
\hline Min. Diameter & $33.10 \mathrm{~mm}$ \\
\hline Insert Geometry & $\begin{array}{l}\gamma=13 \text { deg, } \alpha=7 \text { deg, } \kappa_{n}=12.6 \text { deg, } \\
r_{1}=2.075 \mathrm{~mm}, r_{2}=19.75 \mathrm{~mm}, \\
d_{s}=12.7 \mathrm{~mm}\end{array}$ \\
\hline Edge Preparation & $\mathrm{d}_{\mathrm{ch}}=450 \mu \mathrm{m} \quad \gamma_{\mathrm{ch}}=-19 \mathrm{deg}$ \\
\hline Coating & WC - PVD AlCrN coat \\
\hline \multicolumn{2}{|c|}{ CUTTING CONDITIONS } \\
\hline Cutting Speed & $\mathrm{Vc}=75 \mathrm{~m} / \mathrm{min}$ \\
\hline Feed rate & $\mathrm{fz}=0.066 \mathrm{~mm}$ \\
\hline Axial Depth of Cut & $\mathrm{a}_{\mathrm{p}}=0.40 \mathrm{~mm}$ \\
\hline Radial Depth of Cut & $\mathrm{a}_{\mathrm{e}}=31.25 \mathrm{~mm}$ \\
\hline \multicolumn{2}{|l|}{ Single cutting edge } \\
\hline \multicolumn{2}{|c|}{ Cooled air for chip evacuation } \\
\hline \multicolumn{2}{|c|}{ MACHINE TOOL } \\
\hline Model & DECKEL MAHO DMC70V \\
\hline Structure & double column \\
\hline Axis Travel & $700 \times 550 \times 500 \mathrm{~mm}$ \\
\hline Spindle & $\begin{array}{l}\text { 15,000 rpm } \\
\text { (with temperature control) }\end{array}$ \\
\hline
\end{tabular}

Table 7. Experimental Fixed Conditions for Process Plan with Face Milling (M).

\begin{tabular}{|l|l|}
\hline \multicolumn{2}{|c|}{ TOOL WEAR / COMPOSITION } \\
\hline Stereo Microscope & NIKON MZ12 \\
\hline $\begin{array}{l}\text { Scanning Electron } \\
\text { Microscope }\end{array}$ & LEO 440i, OXFORD \\
\hline \multicolumn{2}{|c|}{ SURFACE ROUGHNESS } \\
\hline Profilometer & MITUTOYO SURFTEST 301 \\
\hline \multicolumn{2}{|c|}{ 3D MEASUREMENT } \\
\hline Measuring Probe & Renishaw MP12 \\
\hline
\end{tabular}

Table 8. Measurement Equipment for Process Plan with Face Milling (M). 
In order to generate a good surface finish, the insert has a special design composed of large radii on the sides $\left(\mathrm{r}_{2}=19.75 \mathrm{~mm}\right)$, joined by smaller radii $\left(\mathrm{r}_{1}=2.08 \mathrm{~mm}\right)$ and circumscribed in a square with $d_{s}=12.7 \mathrm{~mm}$ per side (Fig. 9). The nominal cutting edge angle provided by the cutter is $\kappa_{\mathrm{n}}=12.6 \mathrm{deg}$. The cutting edge preparation is shown in section A-A of Fig. 9. The chamfer size is $d_{c h}=450 \mu \mathrm{m}$ with a corresponding angle $\gamma_{\mathrm{ch}}=-19$ deg. The clearance angle is $\alpha=7 \mathrm{deg}$. The insert material is micro grain WC with PVD AlCrN coating. In order to facilitate comparison with results reported in the literature, a single insert was used in all testing $(\mathrm{z}=1)$.

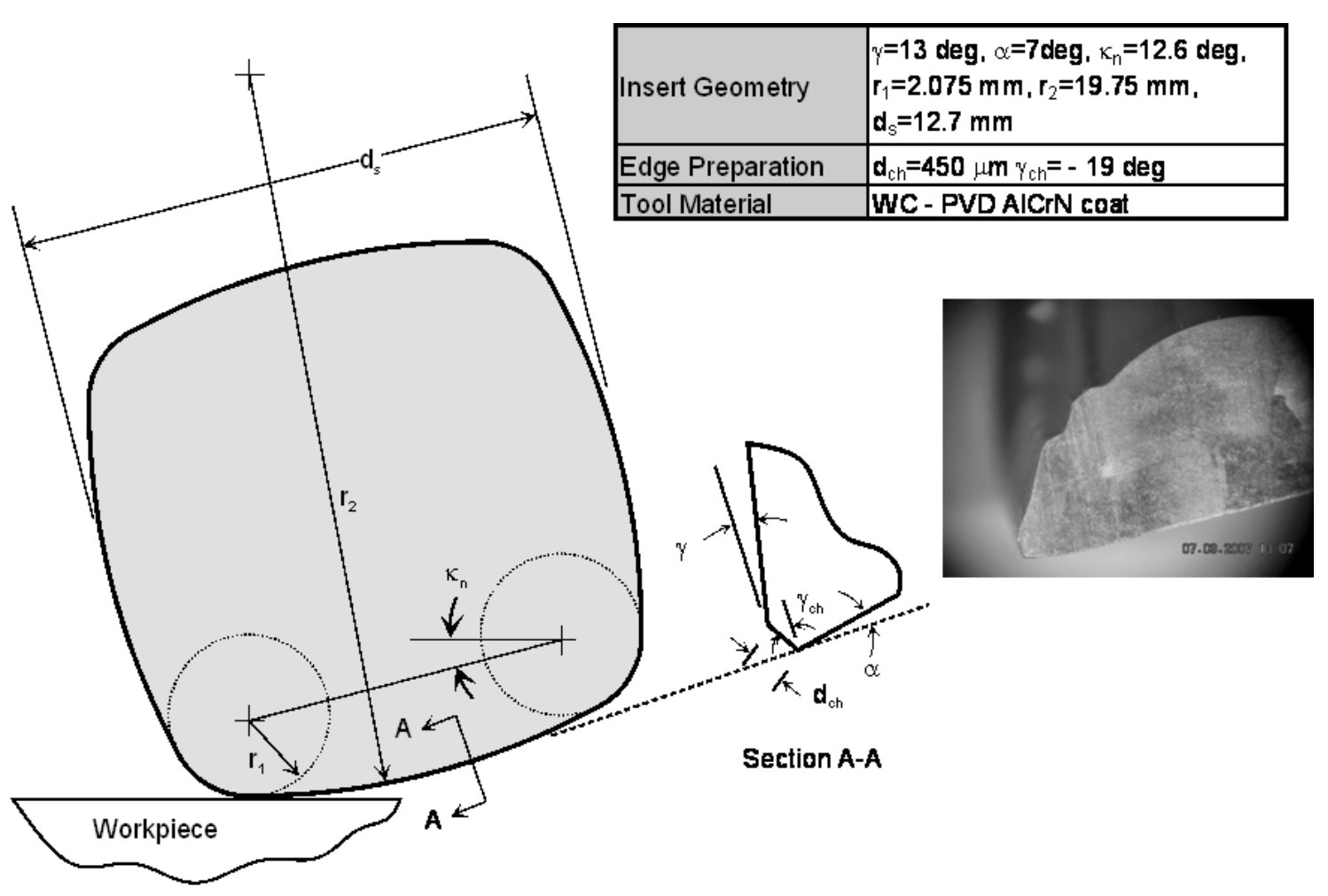

Fig. 9. Cutting tool: insert and cutting edge parameters.

From the technical point of view, the results of the experimentation were satisfactory. The following technical aspects of face milling in hardened AISI D3 steel were evaluated: 
- Process Reliability and Tool Deterioration. The cutting tool deterioration is presented as a regular flank wear without chipping, providing excellent process reliability (see Figure 3.4). Under cutting conditions of $\mathrm{V}_{\mathrm{c}}=75 \mathrm{~m} \mathrm{~min}^{-1}$ and $\mathrm{f}_{\mathrm{z}}=$ $0.066 \mathrm{~mm}$, towards the end of tool life, a significant notch wear appears near the region along the cutting edge $\left(\kappa_{\max }\right)$ that corresponds to the axial depth of cut $\mathrm{a}_{\mathrm{p}}$. The ISO standard for tool life evaluation of face milling inserts [26] recommends a tool life criterion of 800 to $1,200 \mu \mathrm{m}$ for localized wear. Normal practice shows that wear land of 600 microns in localized VB and 300 microns in uniform VB is used, when the roughness is the target. Therefore a conservative criterion of $\mathrm{VB}_{\max }=300$ $\mu \mathrm{m}$ was used in order to compare results with previous related work (Aslam, 2006, Braghini and Coelho, 2001). For this case, the tool life was 26.26 min that corresponds to a machined volume of $\mathrm{B}=15 \mathrm{~cm}^{3}$ after approximately 5 passes.

- Surface Roughness. For the experimental conditions tested in face milling, the surface roughness observed was $\mathrm{R}_{\mathrm{a}}$ between 0.10 and $0.20 \mu \mathrm{m}$ (see Figure 3.4). This level of surface roughness is comparable to that obtained with the surface grinding operation on the same workpiece material $\left(\mathrm{R}_{\mathrm{a}}=0.30 \mu \mathrm{m}\right)$. As shown in Figure 3.4, the surface roughness for $V_{c}=75 \mathrm{~m} \mathrm{~min}^{-1}$ is consistent regardless of having a large localized flank wear on the cutting tool.

- Geometrical Tolerance. According with the results of the dimensional measurements with the touch probe, the flatness variations on a face milled surface of 235 x $157 \mathrm{~mm}$ were approximately +/- $15 \mu \mathrm{m}$. Compared with the achievable geometrical tolerances of surface grinding (Swift and Booker, 2001), the face milling results are within the normal working capability of surface grinding. 
In this study, there was no evaluation of surface integrity in terms of residual stresses and metallurgical changes due to process heat generation. However, previous studies in milling of hardened steels show that the heat generated by this process is not severe enough to produce a micro structural change in the workpiece material (Axinte and Dewes, 2002, Rodriguez et al., 2004).

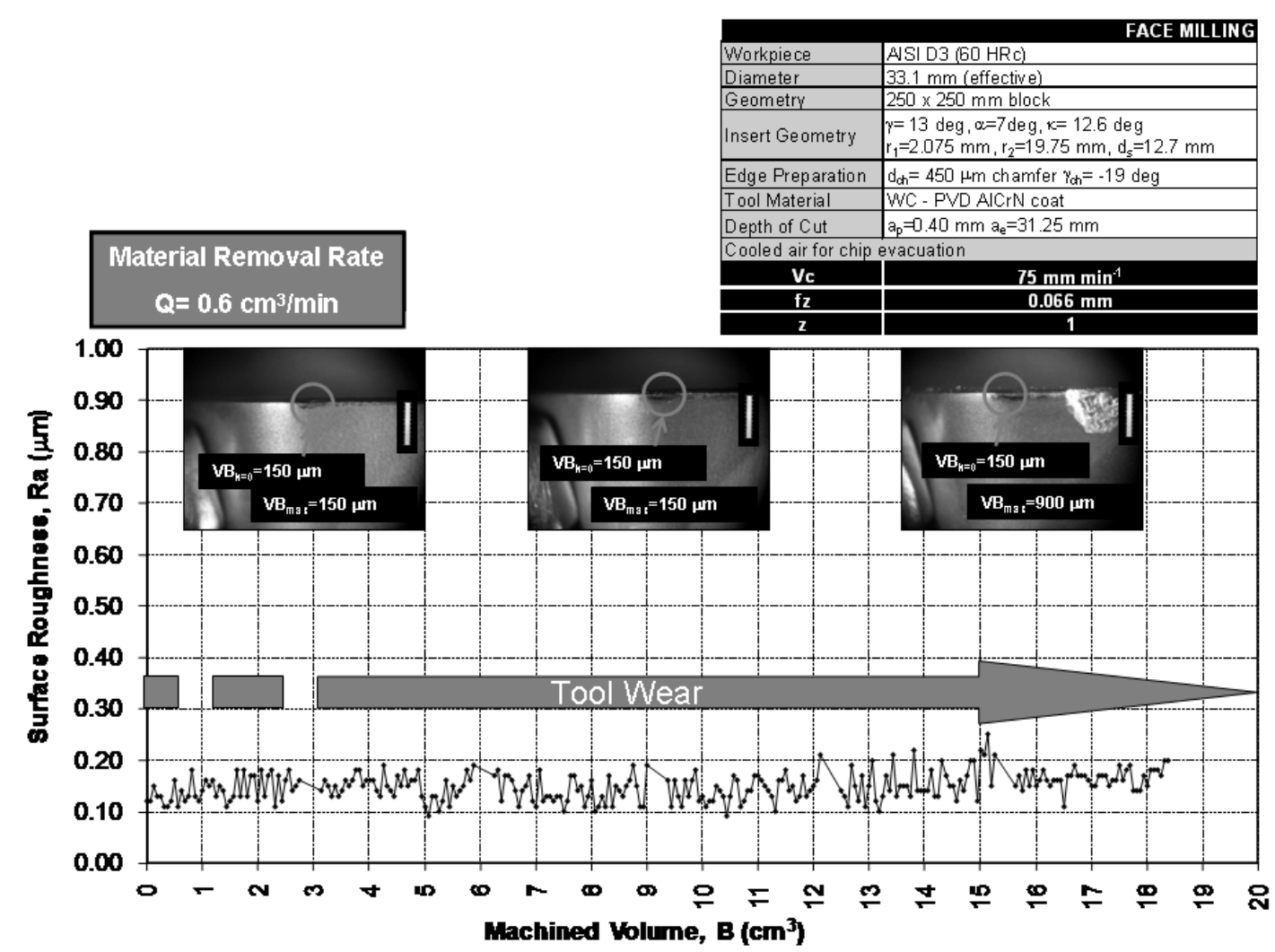

Fig. 10. Cutting tool deterioration and surface roughness for face milling - Process

Plan M.

\section{3. Process Plan with Combination of Grinding and Face Milling (G+M)}

With the same setup and fixed conditions of the previous experiment (Fig. 8) an experiment was conducted, with the purpose of increase material removal rate of the face milling operation, and performs a subsequent operation of surface grinding in order to improve the surface finish $\mathrm{R}_{\mathrm{a}}$ achieved with face milling. In this alternative the objective 
of the face milling operation is not good surface quality but obtaining economical advantage with a quicker operation that will allow the final grinding operation. Therefore, cutting speed was set to $V_{c}$ of $100 \mathrm{~m} \mathrm{~min}^{-1}$ and feed per tooth was fixed at $f_{z}=0.088 \mathrm{~mm}$, under the assumption that with these parameters the productivity will be better and surface quality will be improved with a further grinding operation and according previous experimentation results (Siller et al 2009). Using the same tool life criteria explained before, the tool life was 17.73 min that corresponds to a machined volume of $\mathrm{B}=21 \mathrm{~cm}^{3}$ after approximately 7 passes, before notch wear appears near the region along the cutting edge $\left(\kappa_{\max }\right)$ that corresponds to the axial depth of cut $a_{p}$. Note in Figure 3.5 that the surface finish was $R_{a}$ between 0.10 and $0.30 \mu \mathrm{m}$, and shows more variability than the previous experiment, which results in a less reliable process in terms of surface quality control. Once the face milling operation was terminated, the work piece with stock material is ready for a last pass in the reciprocating surface grinding machine. This process plan involves material handling and support functions which must be avoided or improved in order to decrease non productive time. 


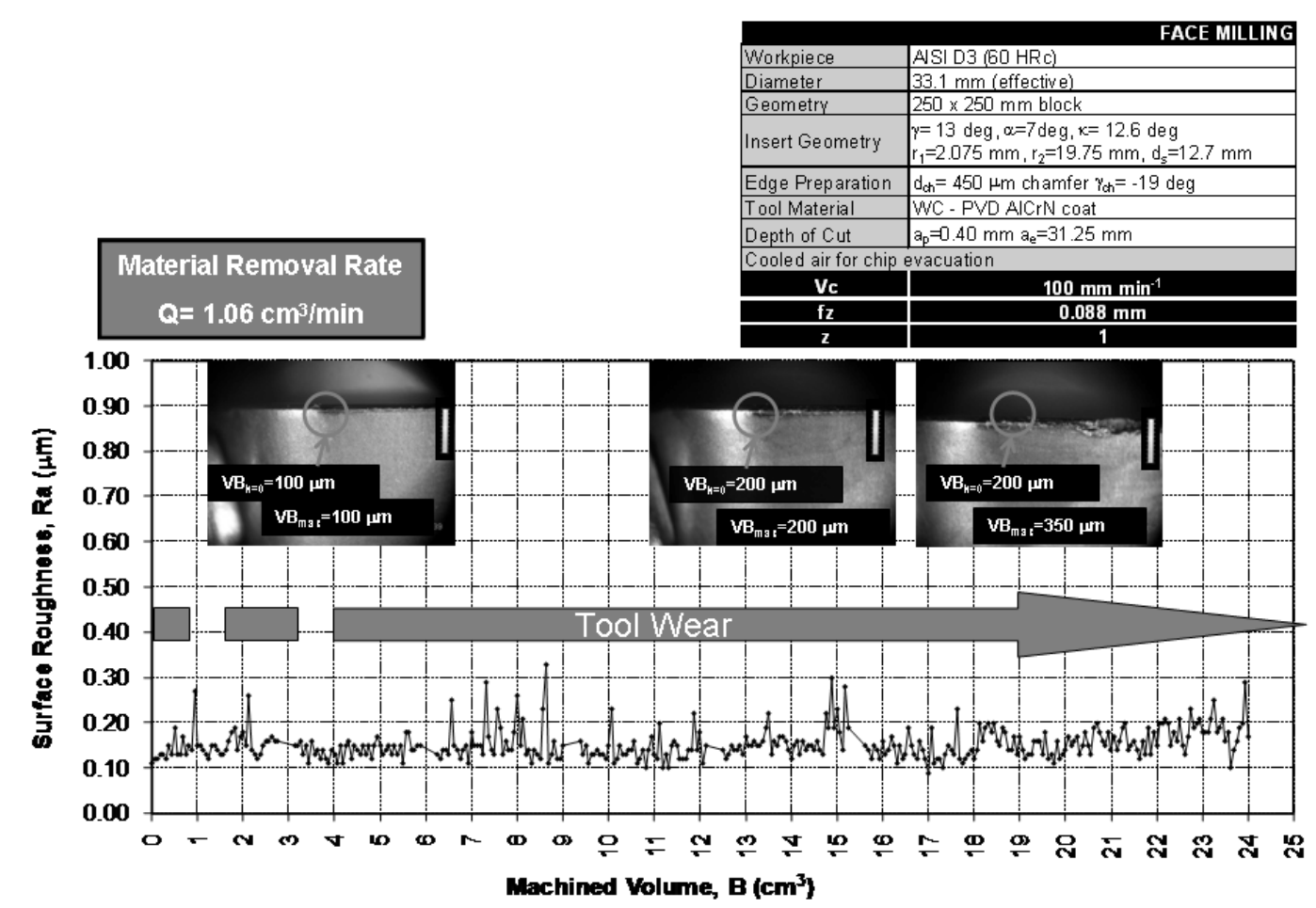

Fig. 11. Cutting tool deterioration and surface roughness for face milling - Process Plan

$$
\mathrm{G}+\mathrm{M} \text {. }
$$

\section{Discussion}

For flat surfaces on hardened tool steel, the comparison of the two process plans developed in this study and previously published results are given in Table 9 and Fig. 12. Some assumptions used in the preparation of this comparative table include:

- For the cases of face milling, the experimental evaluation was conducted with a single cutting edge. The material removal rate used in the calculations is based on the number of cutting edges available in the cutter.

- The non-productive time ratio $r_{n p}$ was based on the actual mould shop production operations with grinding. The same value of $\mathrm{r}_{\mathrm{np}}=1.9$ was assumed in the face milling process plans. 
- The cost of the machine tool hourly rate has been calculated taking into account several real values as machine cost, interest rate, term of lease, monthly payment, property taxes, insurance, repairs, maintenance, electricity and space used. The machine tool hourly rate was set to the same value in all cases.

- The cost of milling inserts for WC and $\mathrm{cBN}$ are reference values based on several sources like tool suppliers, well known tool makers catalogues and scientific literature (Pytlak, 2010).

- The tool life in face milling operations was based on a maximum localized flank wear of $300 \mu \mathrm{m}$, nevertheless the tool can be used beyond that limit with no significant change in surface quality of the work piece.

\begin{tabular}{|c|c|c|c|c|}
\hline & \multirow[t]{2}{*}{$\begin{array}{c}\text { Current Study } \\
\text { Process Plan G } \\
\text { Surface Grinding } \\
\left(\mathrm{Al}_{2} \mathrm{O}_{3} \text { wheel }\right) \\
60 \mathrm{HRC}\end{array}$} & $\begin{array}{c}\text { Current Study } \\
\text { Process Plan M } \\
\text { Face Milling (WC) } \\
60 \mathrm{HRC} \\
V\end{array}$ & $\begin{array}{c}\text { Aslan } 2006 \\
\text { Process Plan } \mathbf{M} \\
\text { Face Milling (cBN) } \\
62 \text { HRC } \\
\end{array}$ \\
\hline & & & $v_{c}=75 \mathrm{~m} \mathrm{~min}^{-1}$ & $V_{c}=200 \mathrm{~m} \mathrm{~min}^{-1}$ \\
\hline \multirow{3}{*}{ 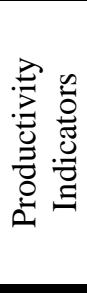 } & $\begin{array}{l}\text { Material Removal Rate, } \\
\text { Q }\left(\mathrm{cm}^{3} \mathrm{~min}^{-1}\right)\end{array}$ & 3.0 & $\begin{array}{l}0.6(\mathrm{z}=1) \\
3.0(\mathrm{z}=5)\end{array}$ & $\begin{array}{l}2.18(\mathrm{z}=1) \\
4.37(\mathrm{z}=2)\end{array}$ \\
\hline & $\begin{array}{c}\text { Non-productive Time } \\
\text { Ratio, } \mathrm{r}_{\mathrm{np}} \\
\end{array}$ & 1.9 & 1.9 & 1.9 \\
\hline & $\begin{array}{l}\text { Manufacturing System } \\
\text { Unit Productivity, } \\
\mathrm{P}_{\mathrm{u}}\left(\mathrm{cm}^{3} \mathrm{~min}^{-1}\right)\end{array}$ & 1.05 & 1.04 & 1.53 \\
\hline \multirow{8}{*}{ ن 苞 } & $\begin{array}{c}\text { Machine Tool Hourly Rate } \\
\left(€ \mathrm{hr}^{-1}\right)\end{array}$ & 15.00 & 15.00 & 15.00 \\
\hline & 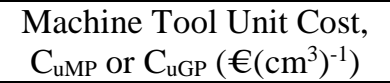 & 0.24 & 0.24 & 0.16 \\
\hline & $\begin{array}{c}\text { Cost per Grinding Wheel } \\
(€)\end{array}$ & 767.00 & N/A & N/A \\
\hline & $\begin{array}{c}\text { Ground Workpiece } \\
\text { Material per Wheel }\left(\mathrm{cm}^{3}\right)\end{array}$ & 45,000 & N/A & N/A \\
\hline & $\begin{array}{c}\text { Cost per Cutting Edge } \\
(€ / \text { edge })\end{array}$ & N/A & 2.50 & 30.00 \\
\hline & $\begin{array}{l}\text { Tool Life per Cutting Edge } \\
\left(\mathrm{cm}^{3}\right)\end{array}$ & N/A & 15.62 & 65.00 \\
\hline & $\begin{array}{l}\text { Cutting Tool / Grinding } \\
\text { Wheel Unit Cost, } \\
\mathrm{C}_{\mathrm{uMT}} \text { or } \mathrm{C}_{\mathrm{uGT}}\left(€\left(\mathrm{~cm}^{3}\right)^{-1}\right)\end{array}$ & 0.017 & 0.16 & 0.46 \\
\hline & $\begin{array}{c}\text { Manufacturing System } \\
\text { Unit Cost, } \\
\mathrm{C}_{\mathrm{u}}\left(€\left(\mathrm{~cm}^{3}\right)^{-1}\right)\end{array}$ & 0.26 & 0.40 & 0.63 \\
\hline
\end{tabular}


Table 9. Cost and productivity comparison of surface grinding vs. face milling for flat surfaces on hardened tool steel AISI D3 (60-62 HRC).

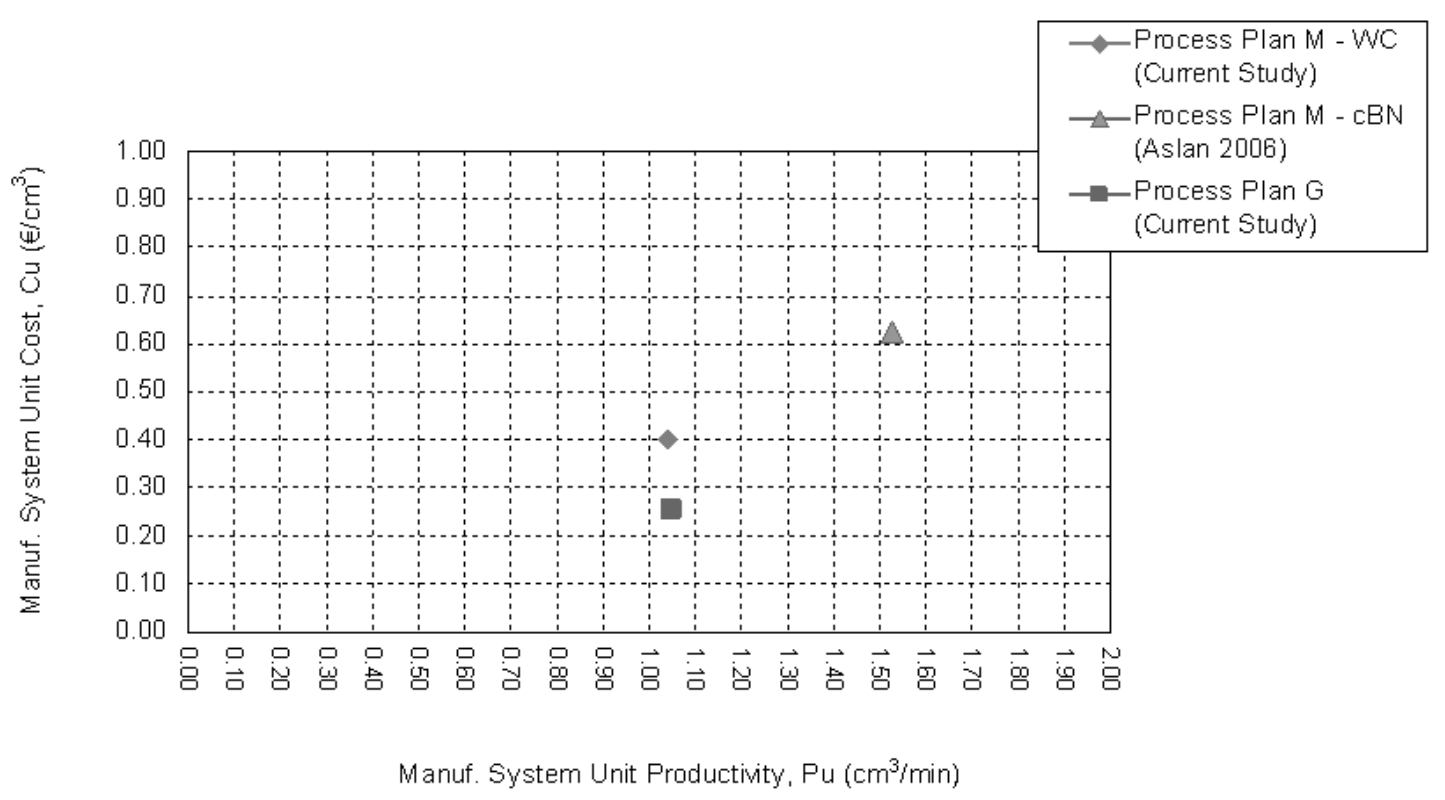

Fig. 12. Economic evaluation of face milling for AISI D3 Steel (60 HRC) and comparison with surface grinding operation and literature results for D3 steel (62 HRc).

The following issues should be discussed about results given in the comparative table:

- Manufacturing system unit cost vs. productivity in grinding vs. face milling. Results of this study show that the productivity reached by face milling is almost the same that the reached by surface grinding, even by using conservatives cutting parameters to maintain surface quality in control. In the case of the manufacturing system unit cost, in spite of the fact that face milling is more expensive than surface grinding, the gradual reduction of costs in the manufacturing of tungsten carbide inserts will improve this indicator. 
- Manufacturing system unit cost vs. productivity in WC vs. cBN face milling. Nevertheless the cBN tool exhibited better productivity than the WC tool, it is required more experimentation in order to assure the reliability $\mathrm{cBN}$ in face milling operations. Also, the use $\mathrm{cBN}$ inserts is still expensive for this kind of machining operation.

The model presented in this work can be implemented in several industrial scenarios where finishing operations of hardened steel are performed. These operations are very common within the manufacturers of moulds and equipment parts for ceramic materials forming. Manufacturing process plans explored in this work are viable alternatives for suppressing the intermediate polishing processes, with its associated cost and time. The current approach for manufacturing process plan selection is limited by the need of extensive experimental data. For the future work we should be able to develop a dynamic method that could meet manufacturing shop floor needs to be more adaptive in each case.

\section{Conclusions and future work}

\section{1. Contributions}

The main contribution of this research is the demonstration of the face milling process viability versus the surface grinding for the finishing of hardened steels flat surfaces components. The development of advanced tools with new geometrical configuration and materials has been made possible this technological approach.

Taking up again the comparison of technical and economic capabilities of grinding vs. hard turning (Figure 1.2) made by Klocke (Klocke et al., 2005)) and adopting it for surface grinding versus face milling of hardened steels, the process reliability, surface roughness and productivity of face milling with tungsten carbide coated inserts are 
competitive factors when deciding the adoption of this technology in tool rooms and shop floors dedicated to the manufacturing of moulds and dies. Furthermore, the use of cooled air for chip evacuation has less environmental impact in comparison to oil and water based fluids used as coolants in surface grinding. Finally, geometrical tolerances reached by face milling are broader in comparison with the reached by surface grinding, but this factor depends on temperature control of the spindle and precision of the machine tool.

\section{2. Future Work}

The study of high performance machining of hardened steels must be thorougly studied through the experimentation of face milling operations with advanced cutting tools made by $\mathrm{cBN}$ and must include economical comparisons with high performance flat surface grinding with cBN wheels, processes available but not widely implemented in the die and mould industry due to the investment needed to carry out their technological demands.

By the evaluation of other machining operations on tool steels in their hardened state, like profiling, drilling, threading and sculptured surface milling, considering cost and productivity analysis, it will be possible to suggest the integration of the whole process plan of material removal operations in a single machine tool, wich means important cycle time and cost savings in the manufacturing of die and mould components.

\section{Acknowledgements}

The research team would like to acknowledge the main support of the Caja CastellóBancaixa Foundation and Universitat Jaume I, which support the project: "Integration of Planning, Execution and Control of High Speed Machining Operations in Collaborative Engineering Environments: Application in Moulds for Tile Industry”, the ceramic tile mould company MACER S.L., and would like to extend their gratitude to Roberto 
Menéndez, student of industrial engineering. Particular thanks go to the Programme Alßan: European Union Programme of High Level Scholarships for Latin America (scholarship \# E04D030982MX). Additional support was provided by Tecnológico de Monterrey through the research group in Mechatronics and Intelligent Machines (http://cidyt.mty.itesm/cimec).

\section{References}

Abdel-Malek, Layek and Asadathorn, Nutthapol. 1996. An analytical approach to process planning with rework option. International Journal of Production Economics 46-47, 511-520.

Alam, M. R., Lee, K. S., Rahman, M., Sankaran, K. S. 2002. Decision algorithm for selection of high-speed machining, EDM or a combination for the manufacture of injection moulds, International Journal of Production Research 40, 845-872.

Altan, T., Lilly, B., Yen, Y.C. 2001. Manufacturing of dies and molds, CIRP AnnalsManufacturing Technology 50, 405-423.

Arnone, M. 1998. High Performance Machining, Hanser Gardner Publications.

Aslan, E. 2005. Experimental investigation of cutting tool performance in high speed cutting of hardened X210 Cr12 cold-work tool steel (62 HRC), Materials and Design 26, 21-27.

Axinte, D. A., Dewes, R. C. 2002. Surface Integrity of hot work tool steel after high speed milling - experimental data and empirical models, Journal of Materials Processing Technology 127, 325-335. 
Ben-Arieh, D. and Qian, L., 2003. Activity-based cost management for design and development stage. International Journal of Production Economics 83 (2), 169183.

Braghini, A., Coelho, R. T. 2001. An investigation of the wear mechanisms of polycrystalline cubic boron nitride (PCBN) tools when end milling hardened steels at low/medium cutting speeds, International Joutrnal of Advanced Manufacturing Technology 17, 244-251.

Bralla, J. G. 1999. Design for manufacturability handbook, McGraw-Hill.

Brinksmeier, E., Tonshoff, H. K., Czenkusch, C., Heinzel, C. 1998. Modelling and optimization of grinding processes, Journal of Intelligent Manufacturing. 9, 303314.

Cavalieri, S., Macarrone, P., Pinto R. 2004. Parametric vs. neural network models for the estimation of production costs: A case study in the automotive industry, International Journal of Production Economics 91, 165-177.

Ciurana, J., Quintana, G., Garcia-Romeu, M.L. 2008. Estimating the cost of vertical high-speed machining centres, a comparison between multiple regression analysis and the neural networks approach, International Journal of Production Economics 115, 171-178.

Coldwell, H., Woods, R., Paul, M., Koshy, P., Dewes, R., Aspinwall, D. 2003. Rapid machining of hardened AISI H13 and D2 moulds, dies and press tools, Journal of Materials Processing Technology 135, 301-311.

Dogra, M., Sharma, V.S., Sachdeva, A., Suri, N.M. and Dureja, J.S., 2011. Performance evaluation of CBN, coated carbide, cryogenically treated uncoated/coated carbide 
inserts in finish-turning of hardened steel. International Joutrnal of Advanced Manufacturing Technology. DOI 10.1007/s00170-011-3320-8

Fallbohmer, P., Rodriguez, C. A., Ozel, T., Altan, T. 2000. High-speed machining of cast iron and alloy steels for die and mold manufacturing, Journal of Materials Processing Technology 98, 104 - 115.

H'mida, F., Martin, P. and Vernadat, F., 2006. Cost estimation in mechanical production: The Cost Entity approach applied to integrated product engineering. International Journal of Production Economics 103 (1), 17-35.

Iqbal, A., He, N., Li, L. , Zha, W. W., Xia, Y. 2006. Influence of tooling parameters in high-speed milling of hardened steels, Key Eng. Mater. 315-316, 676-680.

ISO 4688-1, Tool Life Testing in milling - Part 1: Face Milling, Intl. Standard Org. 4688-1 (1989) 7-15.

Jönsson, M., Andersson, C., Sathl, J.E. 2008. A general economic model for manufacturing cost simulation. Conference paper Conference: 41st CIRP Conference on Manufacturing Systems, May 26-28, 2008, Tokyo, Japan.

Klocke, F., Brinksmeier, E., Weinert, K. 2005. Capability profile of hard cutting and grinding processes, CIRP Annals-Manufacturing Technology 54, 557-580.

Koshy, P., Dewes, R. C., Aspinwall, D. K. 2002. High speed end milling of hardened AISI D2 tool steel (similar to 58 HRC), Journal of Materials Processing Technology 127, 266-273.

Krajnik, P., Kopac, J. 2004. Modern machining of die and mold tools, Journal of Materials Processing Technology 157-58, 543-552.

Lee, C. W., Shin, Y. C. 2000. Evolutionary modelling and optimization of grinding processes, International Journal of Production Research 38, 2787-2813. 
Liu, Z.Q., Ai, X., Zhang, H., Wang, Z.T. and Wan, Y., 2002. Wear patterns and mechanisms of cutting tools in high-speed face milling. Journal of Materials Processing Technology 129, 222-226.

Lopez De Lacalle, L. N., Lamikiz, A., Salgado, M. A., Herranz, S., Rivero, A. 2002. Process planning for reliable high-speed machining of moulds, International Journal of Production Research 40, 2789-2809.

Ozbayrak, M., AkguN, M. and Turker, A.K., 2004. Activity-based cost estimation in a push/pull advanced manufacturing system. International Journal of Production Economics 87 (1), 49-65.

Pytlak, B., 2010. Multicriteria optimization of hard turning operation of the hardened 18HGT steel. International Journal of Advanced Manufacturing Technology 49, 305-312.

Qian, L. and Ben-Arieh, D., 2008. Parametric cost estimation based on activity-based costing: A case study for design and development of rotational parts. International Journal of Production Economics 113, 805-818

Rodriguez, C. A., Cortes, J., Ahuett, H., Hernandez, R., Amado, N., Hendrichs, N. 2004. Evaluation of hard milling and wire electro-discharge machining on hardened D2 steel - Process economics and workpiece surface integrity, SME Technical Papers, TP04PUB362.

Rowe, W. B., Morgan, M. N. 2004. Process Requirements for Cost-Effective Precision Grinding, CIRP Annals-Manufacturing Technology 53, 255-258.

Siller, H.R., Vila, C., Rodriguez, C.A., Abellan, J.V. 2009. Study of face milling of hardened AISI D3 steel with a special design of carbide tools, International Joutrnal of Advanced Manufacturing Technology 40, 12-25. 
Swift, K. G., Booker, J. D. 2001. Process Selection. From Design to Manufacture, Butterworth-Heinemann.

Toh, C. K. 2006. Cutter path strategies in high speed rough milling of hardened steel, Materials and Design 27, 107-114.

Urbanski, J. P., Koshy, P., Dewes, R. C., Aspinwall, D. K. 2000. High speed machining of moulds and dies for net shape manufacture, Materials and Design 21, 395-402.

Vila, C., Romero, F., Galmes, V., Agost, M. J. 2005. Collaborative solution for cooperation, coordination and knowledge management in the ceramic tile design chain, Lecture Notes in Computer Science 3675, 86-93.

Vivancos, J., Luis, C., Costa, L., Ortiz, J. A. 2004. Optimal machining parameters selection in high speed milling of hardened steels for injection moulds, Journal of Materials Processing Technology 155-56, 1505-1512.

Wang, P., Liang, M. 2005. An integrated approach to tolerance synthesis, process selection and machining parameters optimization problems, International Journal of Production Research 43, 2237-2262.

Webster, J \& Tricard, M. 2004. Innovations in Abrasive Products for Precision Grinding, CIRP Annals-Manufacturing Technology 53, 597-617.

Webster, J. 2004. High Efficiency Deep Grinding (HEDG) - Theory and Practice, SME Technical Papers (2004) TP04PUB367.

Wright, P. K., 2001. 21st Century Manufacturing. Prentice Hall, New Jersey. 


\section{List of Figure Captions}

Fig. 1. Cutting tool geometry, machining operations and their respective application in die and mould component manufacturing.

Fig. 2. Capability comparison between hard turning and cylindrical grinding (adapted from Klocke 2005).

Fig. 3. Recommended processes as a function of surface roughness for flat surfaces on hardened tool steels.

Fig. 4. Process plan alternatives for flat surfaces on hardened steel and a surface roughness range $R_{a}$ between 0.2 to $1.0 \mu \mathrm{m}$.

Fig. 5. System unit productivity and cost.

Fig. 6. Experimental evaluations with face milling and surface grinding on hardened tool steel.

Fig. 7. Experimental setup in flat surface grinding.

Fig. 8. Experimental setup in face milling.

Fig. 9. Cutting tool: insert and cutting edge parameters.

Fig. 10. Cutting tool deterioration and surface roughness for face milling - Process Plan M.

Fig. 11. Cutting tool deterioration and surface roughness for face milling - Process Plan $\mathrm{G}+\mathrm{M}$.

Fig. 12. Economic evaluation of face milling for AISI D3 Steel (60 HRC) and comparison with surface grinding operation and literature results for D3 steel (62 HRc). 


\section{List of Table Captions}

Table 1. Nomenclature in order of apearance.

Table 2. Comparative of typical values of parameters for hardened steels.

Table 3. Matrix representation of process plan alternatives for flat surfaces on hardened steel and a surface roughness range $\mathrm{R}_{\mathrm{a}}$ between 0.2 to $1.0 \mu \mathrm{m}$

Table 4. Factors related to the productive and non-productive time

Table 5. Factors related to the machine and cutting tools/grinding wheel cost

Table 6. Experimental Fixed Conditions for Process Plan with Grinding (G)

Table 7. Experimental Fixed Conditions for Process Plan with Face Milling (M)

Table 8. Measurement Equipment for Process Plan with Face Milling (M)

Table 9. Cost and productivity comparison of surface grinding vs. face milling for flat surfaces on hardened tool steel AISI D3 (60-62 HRC) 